\title{
$(200)$ $\mathrm{T}_{6} \mathrm{Y} / 2$
}

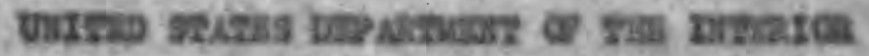

ososostos sarax

gsochersent a maqustur

wy

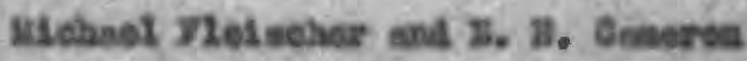

Jane 194

Zrees Slebente Inventscationa - Report To.

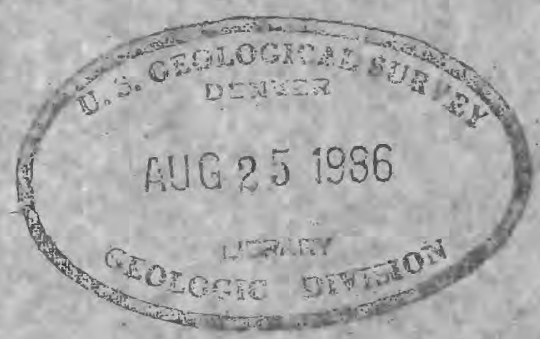


Abstract

Introciuetion

Ceochenteal Conalderatione

Genersal Statesent

Occurrences in specifie siserals and rocke Index of ainerile linted

Beryl

Uiserale in whfoh beryllium in in essentinl cosstituent

ilinerals in whlch beryllives is s minoz, sccessory consti tuent

alockes

Cosl ashes

ilemalts of mbli protact strdite

Best sources of beryllins

faccentions for furthex investications

innotated biblogreping of occurreneas of bery 111 an
2. 1

P. 1

P. 2

P. 2

P. 4

7. 6

P. 6

P. 9

P. 12

P. 12

T. 25

จ. 15

7. 19

3. 22

Table I - Best values of bery 115un frea pectroeraphle study of mi11 prodacto

Fable II - Berry production and reterres, Undted Stetes

P. 24

ร. 17

Table II - Forelen proctuction of baryl.

ร. 18 


\section{Gecenarsir ex macturear}

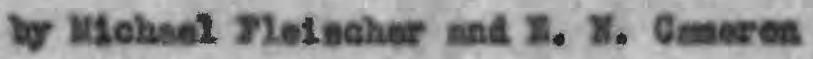

\section{ABstracs}

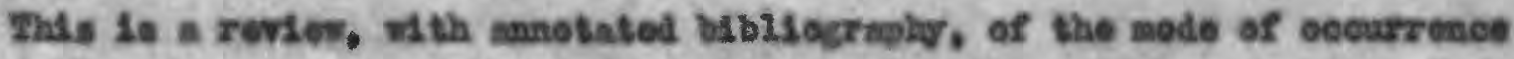
of the elesent berglilus, It it not a 14 st of meelfie ore deponits, but a

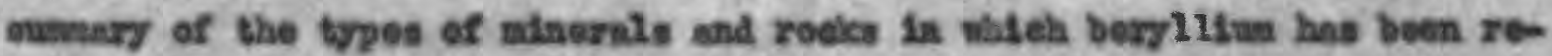

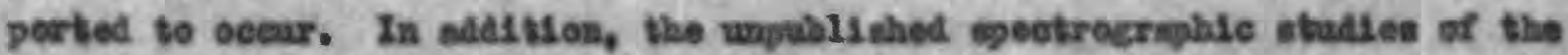

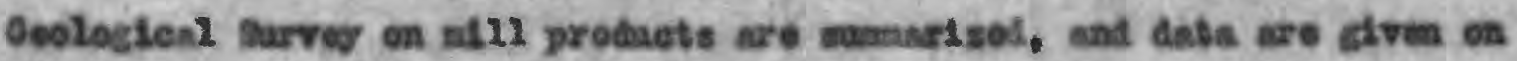
doaeatie produet1on and reterves and on forelon profuetion.

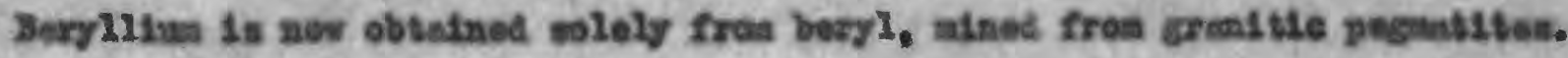

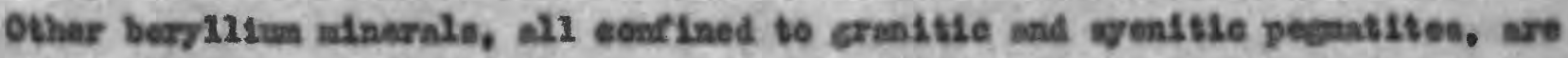

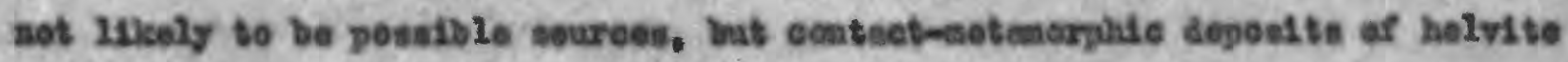
of eomereinal grede alcht potalbly be found, Sucseatlons are asde for forther Investlgatless, Fiticularly of methode of coneentratine low-erade beryl ores, and of the oecarrenee of beryLlium in herienn coele.

\section{Denctucsuca}

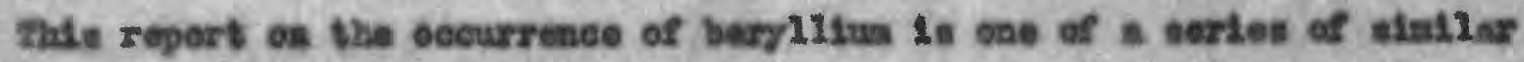
roperta propered if the Geologleal Survey discusalng posilble scurcen of rare of whedimen elesents that hod epeet nx war wats.

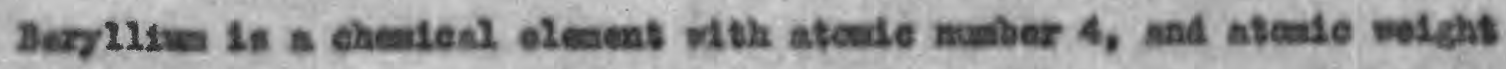
9.02. It belonge to the seoond gnvieg of the perioffe table and is bivalent in $16 \mathrm{~s}$ ecesporands. 


\section{$-2$

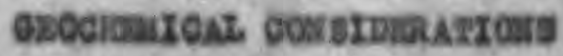 \\ Gesterel statenent}

Jergilive Is a relntively rare elosent. Recent entlinates (1, 6, 13) Ifve 0.0005 to 0.0006 percent Be for the coutent in the sarth's crust.

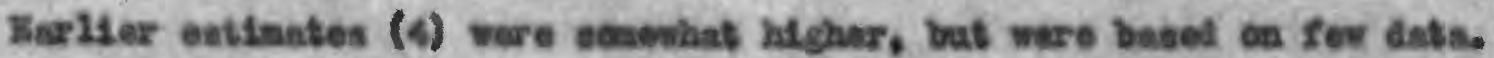
Berglitem is a Lthephilic elenemt, found shont exclusively in 1 gavous and sedinentary rockch. In contrient to alsperaed elenents mela se gellive or

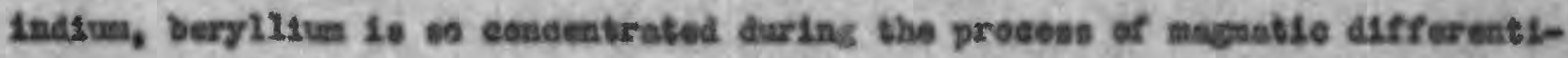
ation that it in a major conotitwent of mony minerals. These minerrels, aliost

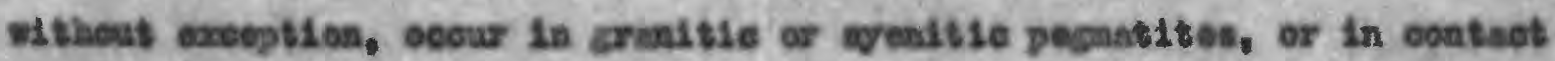
net enorphle depostiva.

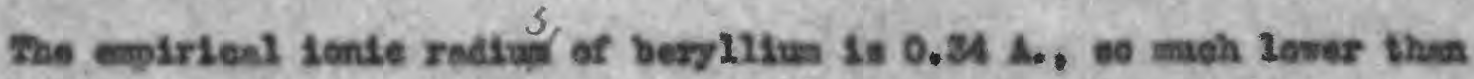

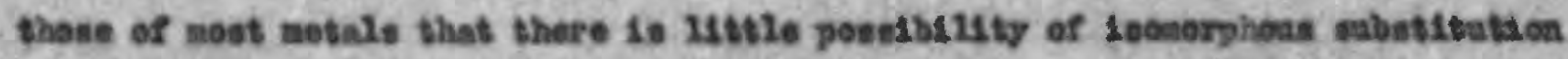

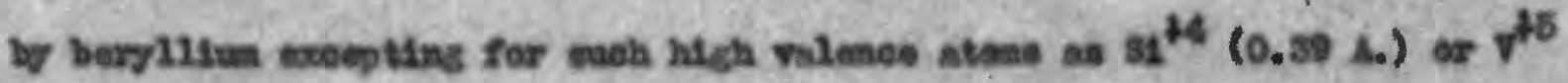
(0.4 A.). Fueh posadble subatitutiona involve conplosx valeneg adfustaents

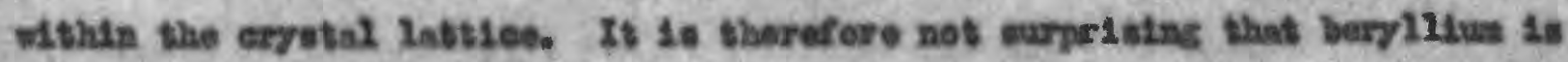

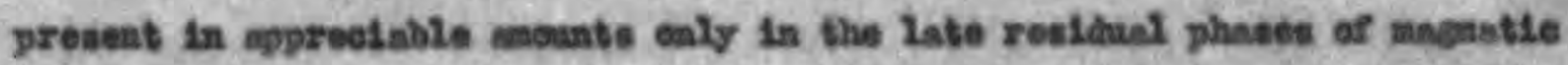
notivity.

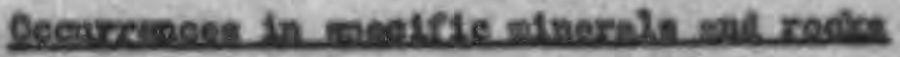

She follosing in ineludes all the minerale that have been reported to

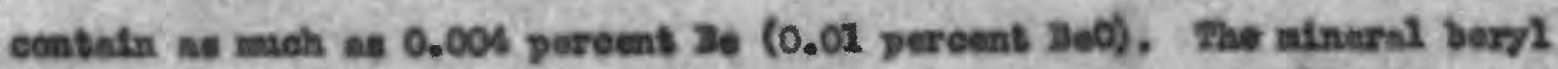
18 the ealy cosacerelel source at present and is therefore diseutaed firat wades (1). The other minerals have been drided Into two groups: (2) Wineraln in which berylliam is an esenti-l centitituent, and ( 3 ) Minorals in

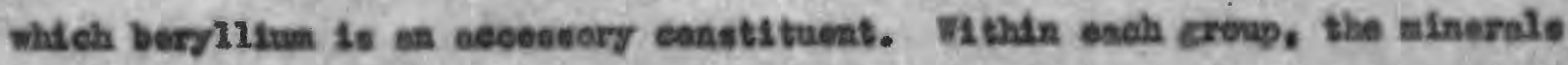


are mabdivided inte chealesl eleveee and are listed alphabetienlly within

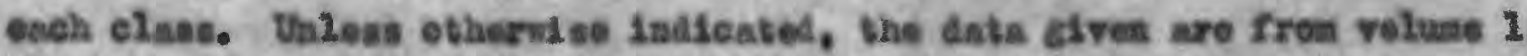
of the Seventh Xastion of Dane's Eystea of uineralogy and froe the alneralogleal

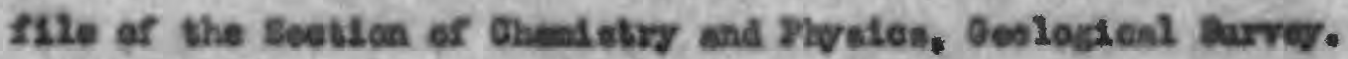




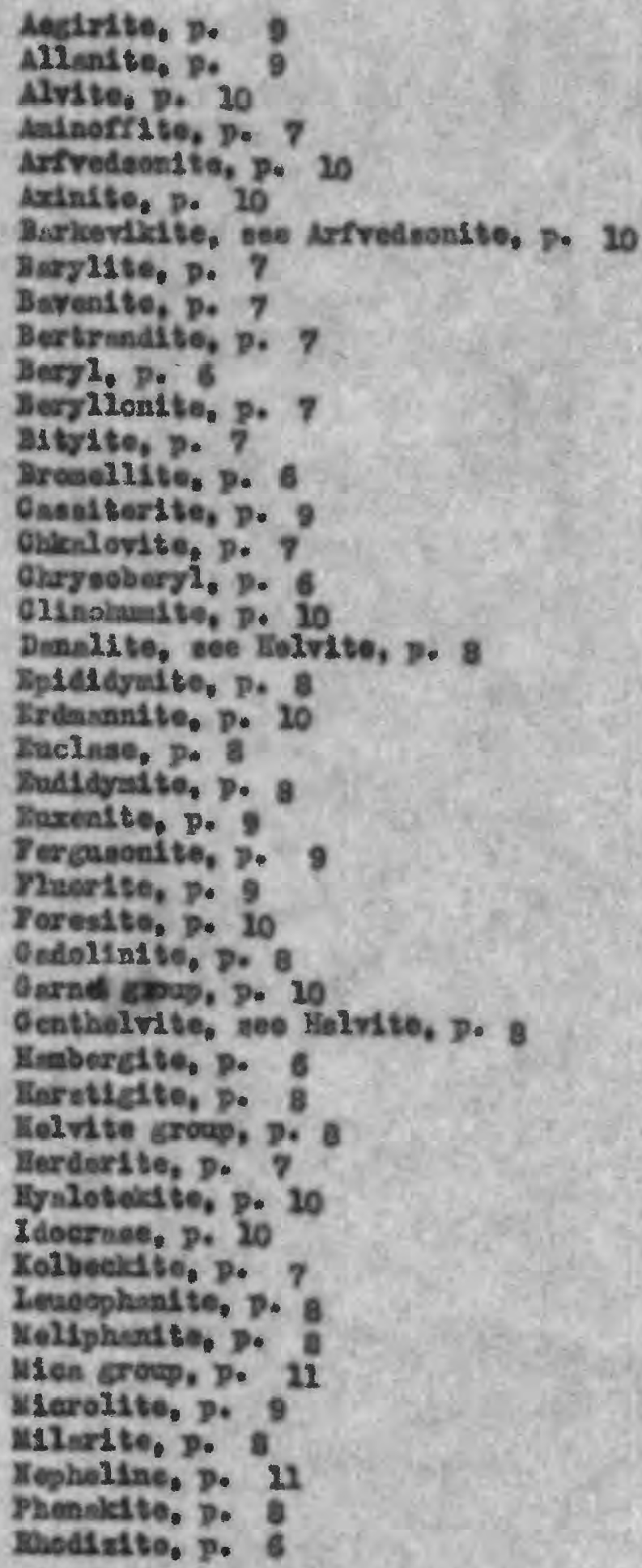

\section{zereent 3 en}

Dp to 0.04

Up to 0.3

Do to 0.5 2.2

Up to 0.01

Up to 0.04

$$
\begin{gathered}
5.7 \\
1.2 \\
15.1 \\
7.1 \\
0.8 \\
36.0 \\
4 r 500= \\
4.1=4.6 \\
7.1
\end{gathered}
$$

top to 0.6

$$
\begin{gathered}
3.7 \\
1.0-1.5 \\
6.2 \\
8.7
\end{gathered}
$$

Is to 0.08

Do to 0.14

Treces

$$
0.25
$$

3. $2-4.7$

up to 0.04

$$
\begin{gathered}
19.2 \\
4.0 \\
3.8-5.4 \\
5.6-5.9 \\
0.37 \\
5 p 50.39 \\
3.1 \\
4.0 \\
3.4-5.0 \\
0.0 .0 .04 \\
0.13 \\
1.8
\end{gathered}
$$

Up to 0.0214

16.4

$$
3.6-5.4
$$

\section{Tron of Coesrtenes}

syanitie pecastite

Verionas

franltse pegatite

Contaes setwarplufe 1

syenitic pecmetste

Fineumatolytic

Contret setenorplace

Grenitic pesnatite<smiles>CCCCCC</smiles>

Grositie peountite

"

a

Contwes aetmorphe

Orasit1e pegsetite

gyenitie peajatite

Oranitie pearatite

Contmes metenorphate

Keprouline orend te

Grastic pegantite

Tephelino sqeal te

orinitie pogantite

is

Contset metenorphle

Grintile ad wenttie

Contnet metenorphie

Varleus

Granitie pegantite

Contines mot masphle

ล

Iydrothemal

srenste perastite

Uranitie pegastite

ox $\sin 1$ tie pegantite

$$
\text { " }
$$

Yepheline wenitse

Grinditle pogratstes 
Indez of afnerals listed - (Continaed)

Semeraldte, p. 9

Stecnetrupine, P. 11

Svedenborictte, p. 7

Tenger 1to, $\mathrm{po}$. 6

Thorlts, $\mathrm{D}, 11$

zounsiline, po 11

Jrianorite, p. 8

Techer netinitie, $p, 21$

Vratalts, D.

Vesurdend te, age Idoorate, p. 20

Sovelute, $p$.

rttrotantelite, p. 9
Up 0.11

$0.45-0.69$

12.6

3.5

Up to 0.01

Up to 0.04

$$
8.1
$$

Up to 0.7

is to 0.004

0.20

UD $\$ 0,0.22$
Orant tie pegnatite

frent te peonatite

Coatsect setimerphle

Crandite peosentite

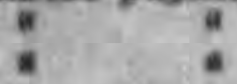

Contset netinomple orenitle pegantite ,

I

seeondery alnersl

orisdile pegantite 


\section{(1) $3 \operatorname{err} 2$}

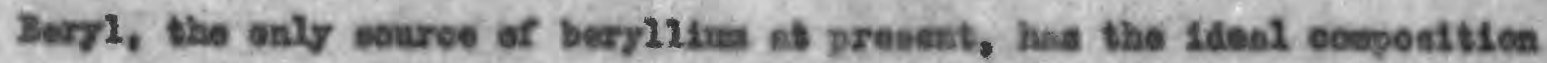

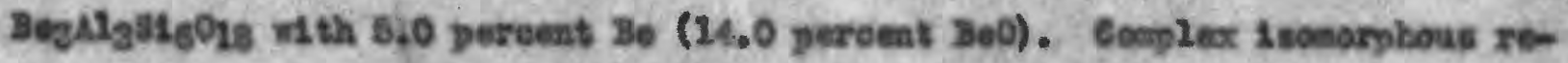
placenent, includinc the introduction of water and the alkelles, esaees the

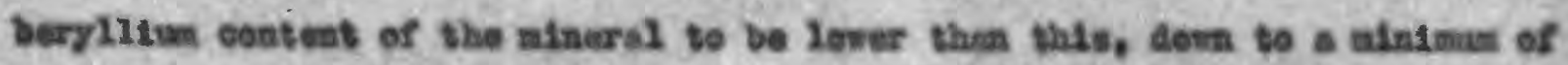
About 3 pereent Be. The earnon Fiage of berylliun content in beryl is 3.8 to 4.6 percent 30.

Jeryl oecure in alnabie abounts alnost exolasively in grindtie pegatites. A revlew of world deponsts ass recently been publiched in Iraseles (a3).

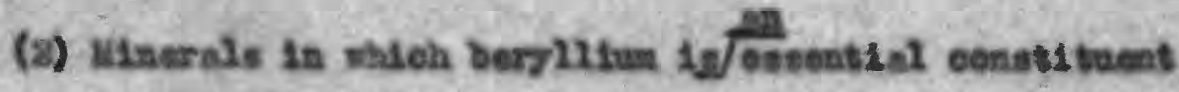

\section{(a) Oxdes}

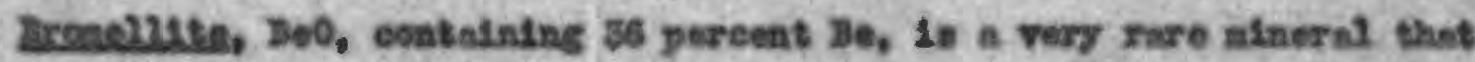
occurs in s coatect-metinorphle elosra.

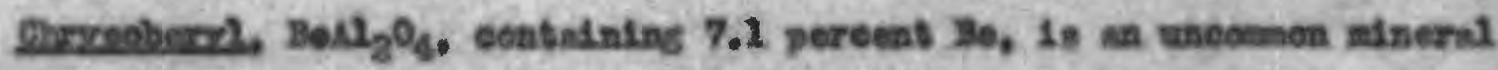

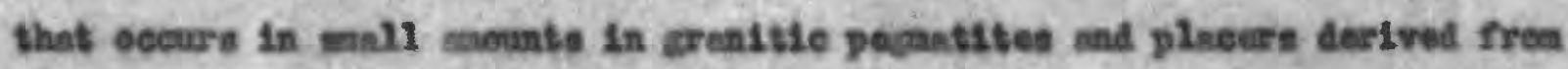
then, also in wios sobisto.

(b) Garbonate and borntes

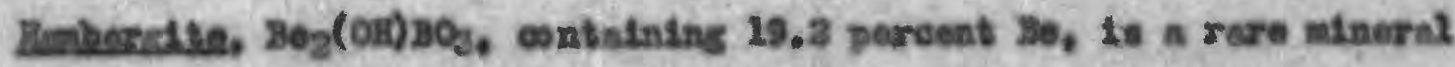

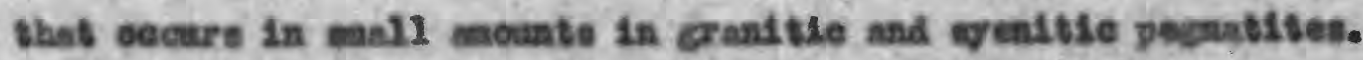

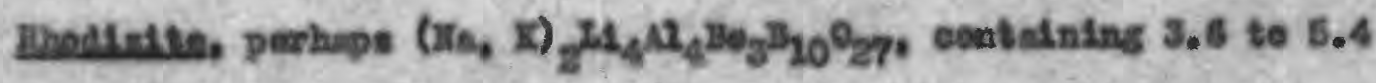
pereent Be, is a very rare alnersel that eccurs in enell equnts in croaltie peganbites.

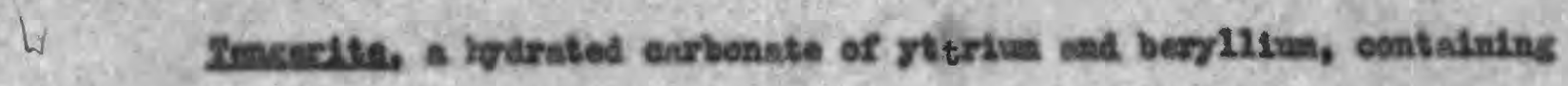

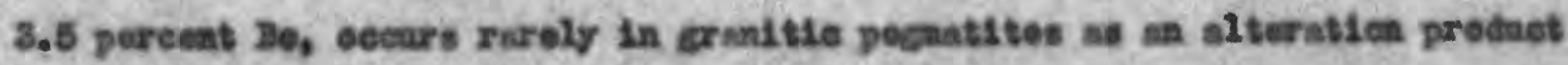
of sedolintte. 
(c) Phomplates, Ant1monste

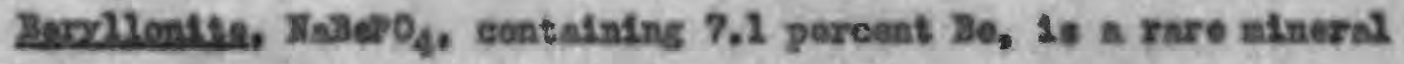
that oecurs in all sapunts in ernitic pognetites.

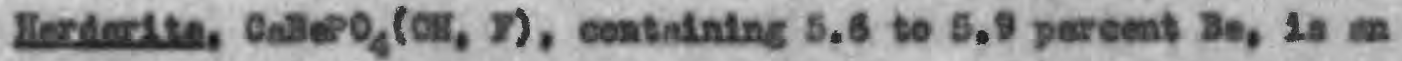
unoocsen sleeral that oecure in sinil saounts in eranitie peonstites.

rolbeoldte in a very rare lydrated exicophosphate of boryllium,

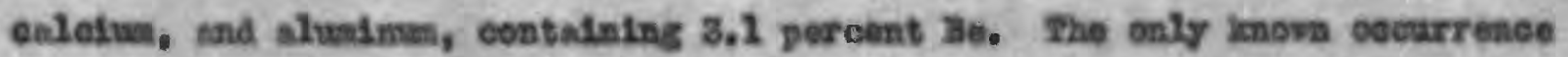
is in a quastamolfradte vein.

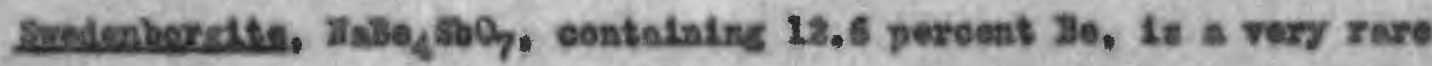
alneral that is found at one loeslity in a contaot notemorphle eloposit.

(d) silicates

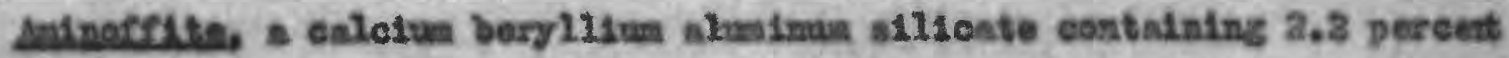
Je, is a very rare miner al that occurs in velns in angnetite in a contact metamorphle deposits.

Besclite, $30 \mathrm{e}_{2} \mathrm{HL}_{2} \mathrm{O}$, coutaining 5.7 pereent Be, is a very reve mineral

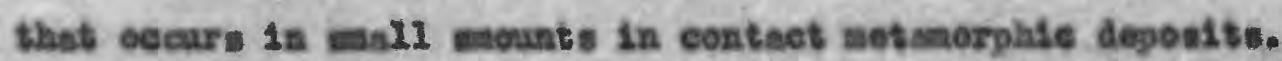

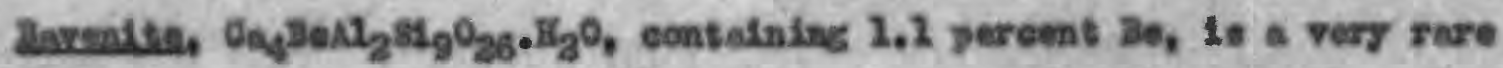
atregal that oecurs in manl esounts in cronltie pegantites.

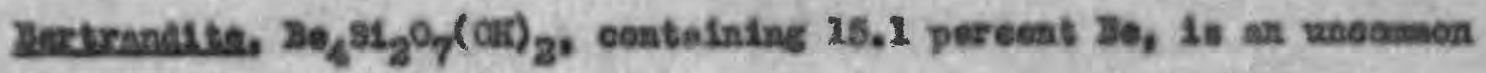
minerel that eccurs in very mall gonounte as an alterntion product of beryh in Granitic peoatites.

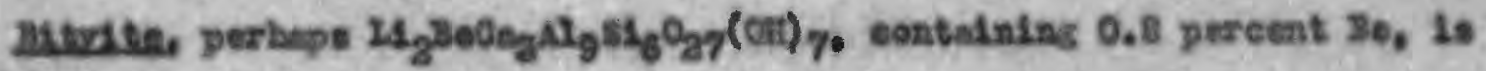
A very rare minersl. The only lewown occurrmet is in a crandtie pegatite.

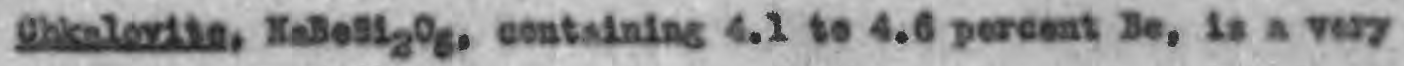

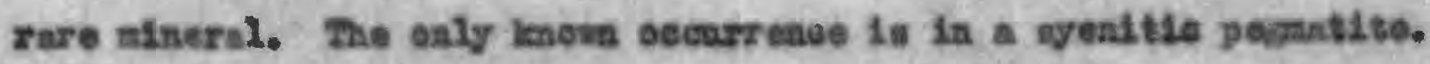




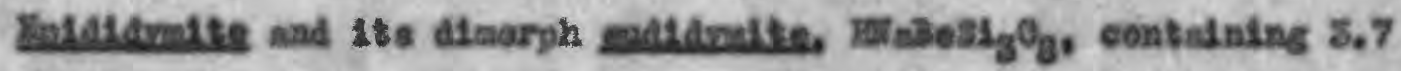

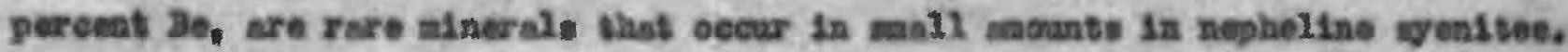

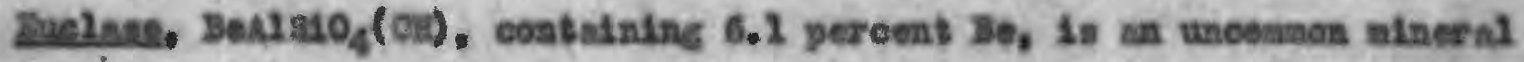

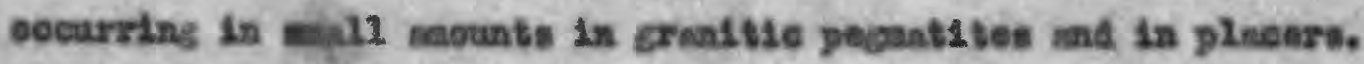
Gedolinite, $\mathrm{Ze}_{3} \mathrm{I}_{2} \mathrm{Fesi} \mathrm{O}_{2} \mathrm{O}_{2}$, eontalining 3.2 to 4.7 percent $\mathrm{Be}$, is an unoomon mineral that oecure in eranitle pegantites, but only rarely in larse nesounte.

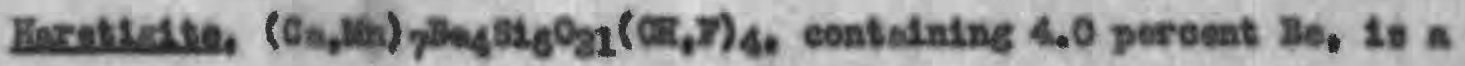
very sare minernd that oceurs in contect metmoorphle deposits.

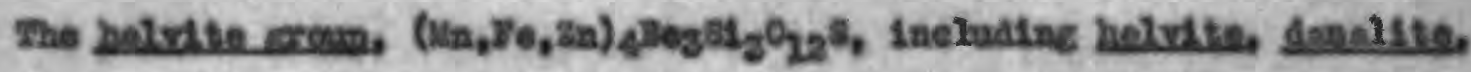

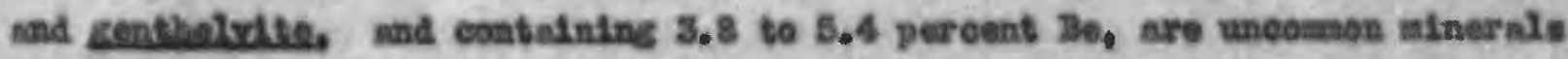

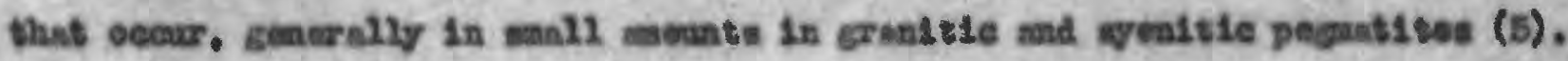

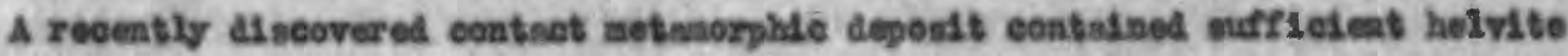
to be conediered as a pesetble source of berylitua (10), and other atalis deposits say heve been overlooksd.

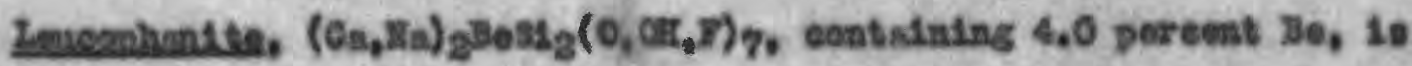

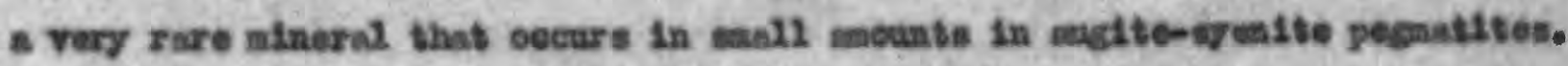

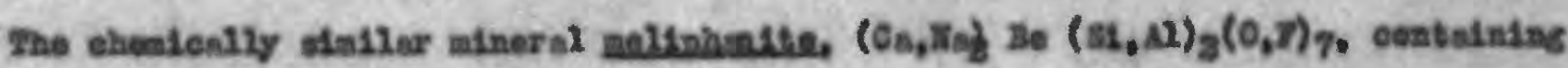
3.4 to 5.0 percent 30 , is a vary rure mineral that oecure in moll gabunte in grealtie pegatites.

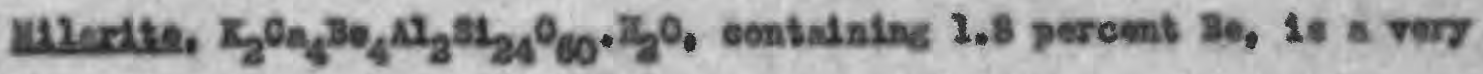

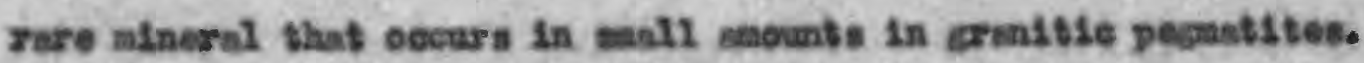

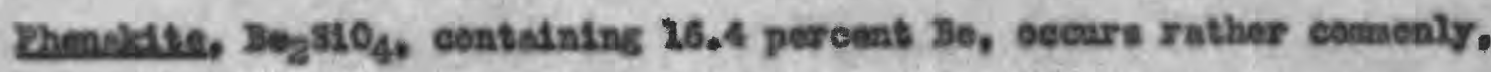

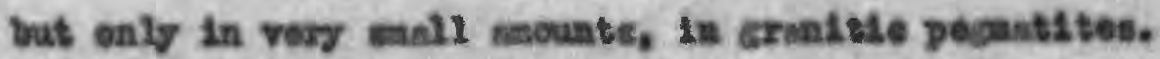

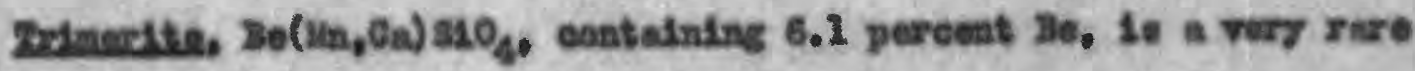
idneral that oecurs in mell mounts in contact wetinorplate depoits. 
(3) Minerels is which berilim is a miner, sccessoxy seantituent

\section{(a) Cadass}

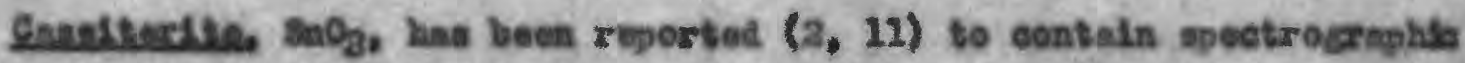
traces of beryilim.

Drentnite has been regorted to contain bery 114 us (14), but no sampio feated eontadned wore then 0.004 percent 30 .

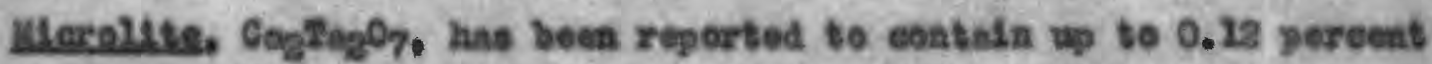

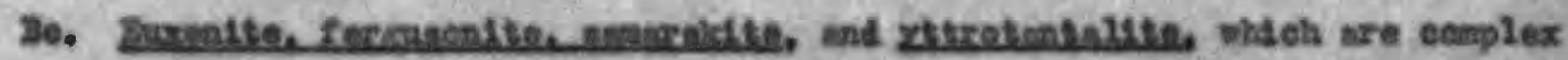
eoluabate-tentelates of the rere esrths, have been reported to eontale up to 0.2 pereent 3e. They oecrur in granltie pesmatitas.

\section{(b) Halides}

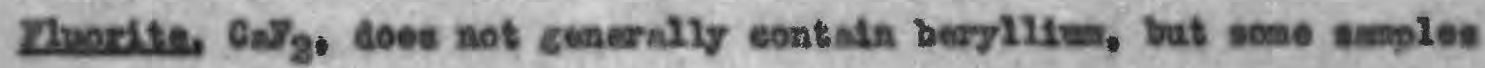
froe crealtie pecentites heve been found to eontaln treees of berylium (26).

(c) Phosplastes

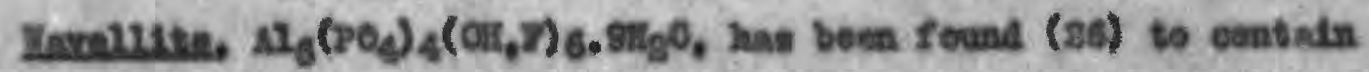

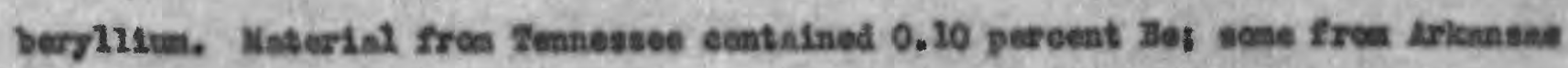

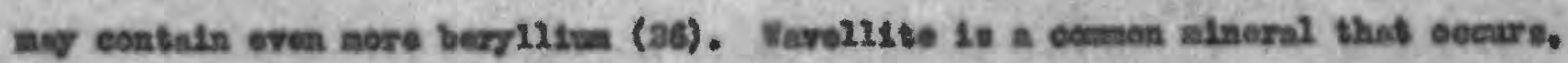
tmanly in manll mounts, as a secondery mineral.

(d) sillentos

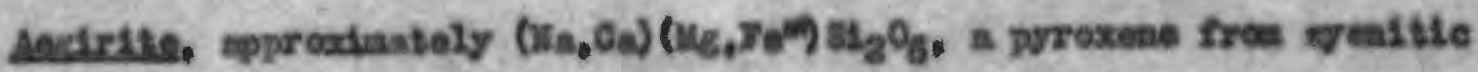
pecalutes ans been reportsd $(7)$ to eontala up to 0.04 poreent Be.

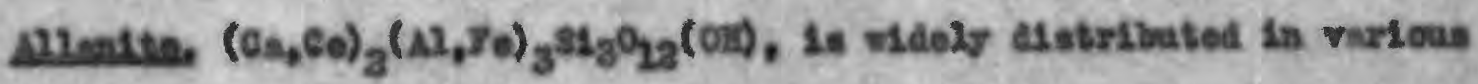
roek types, Genersily in mall enounts. Woot suples contain a for bandredths of a percent of beryllium, but exceptionol seaples have been reported to contaln wp to 2.0 pereent Be. 


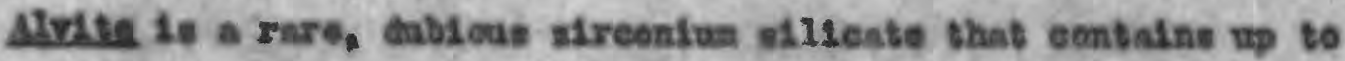
5 peroent $\$$ e, socordine to old malyseet.

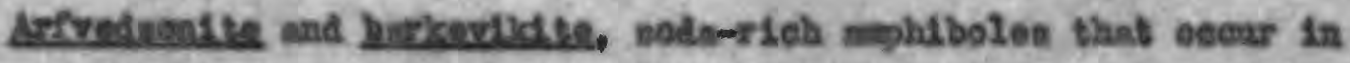
cremstle rocics, ere reported (7) to contaln up to 0.01 percent 30 ,

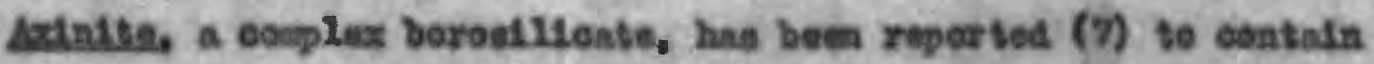
0.04 percent Be. It is a ogmon wineral that ocours in sanil cobunts in paecantolytie seposits and in the conteet sones of soae grasites.

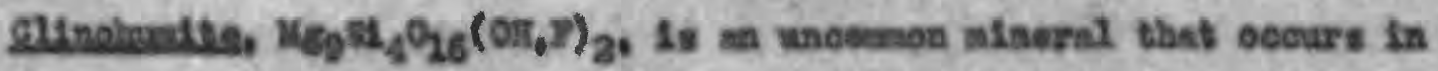

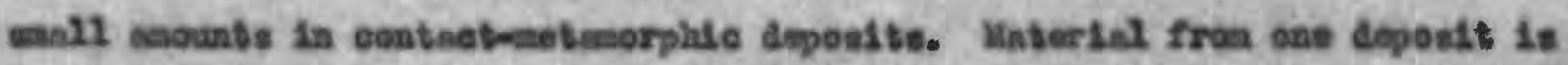
reparted (23) to contalin 0.6 percent Be.

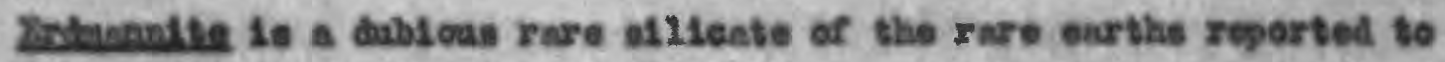
contadn 1 to 1,5 pereent De.

Zexeste is a dublous rare seollte that ocoss in a grand bie pecatite Fo malyeen abow 0,35 percent Be.

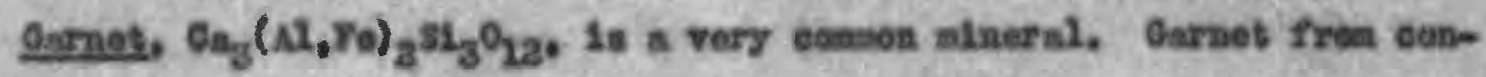

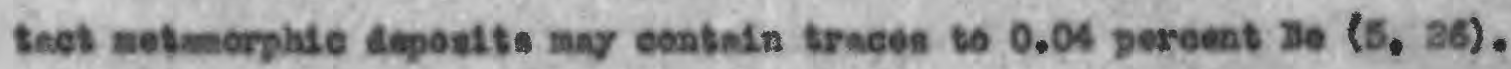

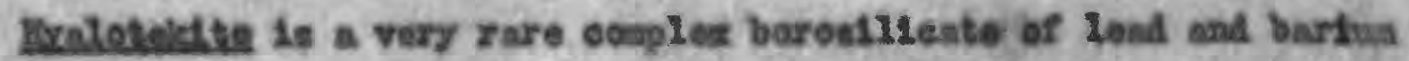
lenown ouly fron one contset metheorplale deposit. It eentalas 0.37 pereent He.

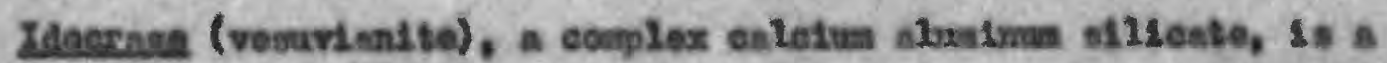

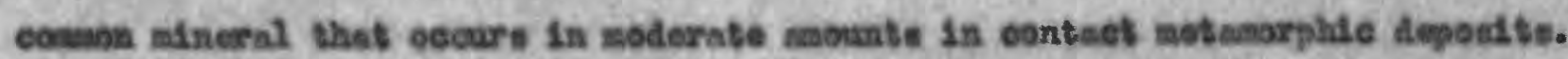

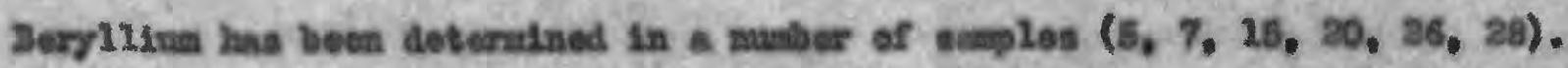

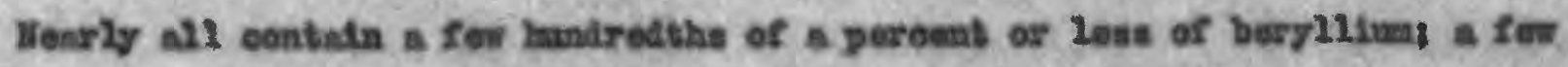
contale nors. The Mloheat verifled content 1 s 0,39 percent $36(5)$; the report (15) of a congle wth 3.3 percent Be is quentionable. 


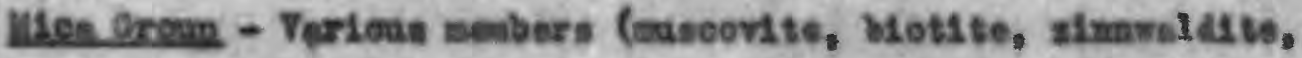
Iepidolite) of the ales grow that oectr in ernatile peoastite here been found $(7,26)$ to contaln trnees to 0.04 percent 80 .

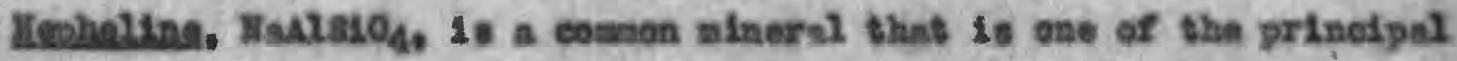

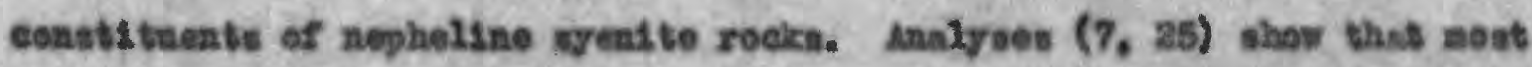
nephelines contain berglitum, the baximan pereentige found betsg 0.014 and the âverage 0.005 percent De.

Sitemabrutine is a very rare conplex phamphate-allieste of the rare

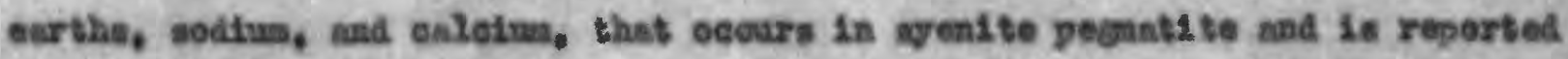
to eontein 0.48 to 0.68 percents 80 .

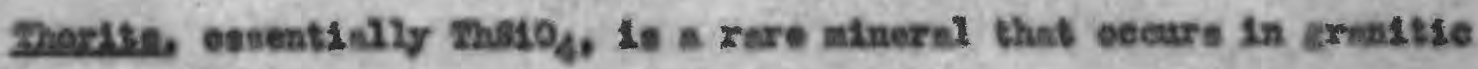
peonatites. It is reported $(14)$ to eontain wo to 0.01 pereent Bo.

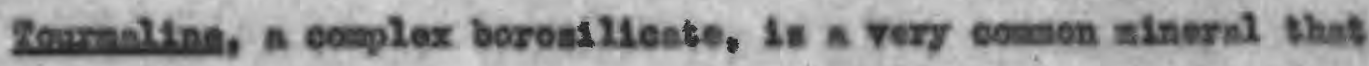
occurs in granitie pegatites. It eonbalins truces to 0.04 pereent Be $(7,35)$. Fechefednite (ehovidalte). Is a rars, complex ad1leste of eerium,

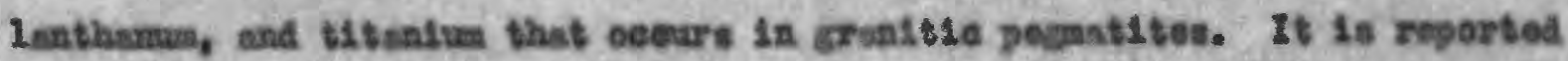
to contedn up to 0.7 perceat 30 , 
Rocks

The averace content of bergiliun in the eir th's cruet has been estianted to be 0.0005 to 0.0006 poreent 30. Host rocks have Lovir bery/11um

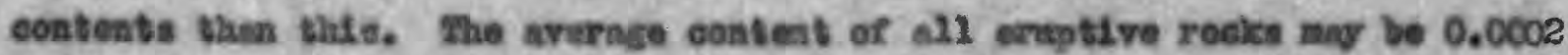

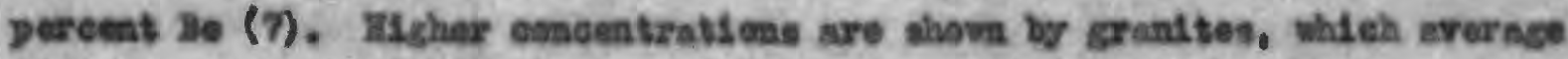
perhape 0.0007 persent $3 e(7,9,17,28,19,20,21)$ and by neghitine areastes, which mey nverege 0.001 to 0.004 pereeat $30(7,9,19)$. Contuet netwaerphle

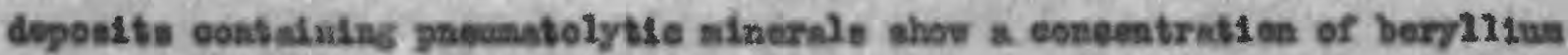

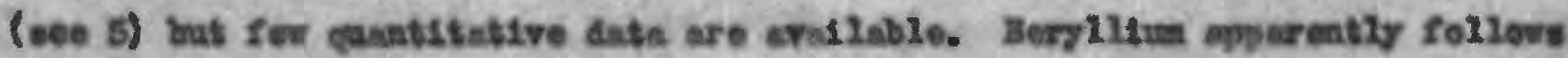

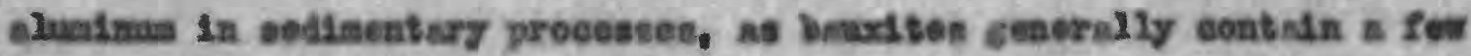
thounsolthe of a percent $(7,21)$, Cloge and elog sehlats appent to have slichty

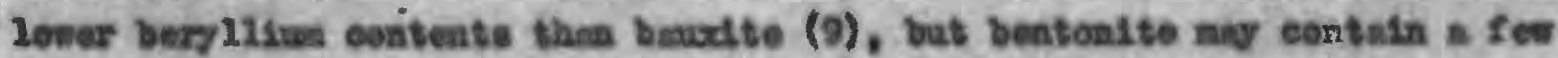
zandredtic of a pereent of berriliva (26).

\section{Ooel sulhos}

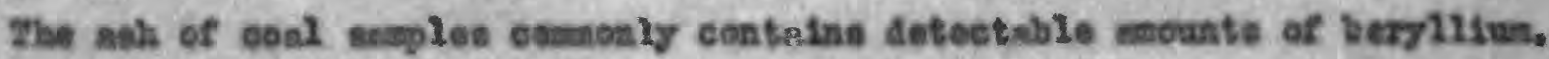

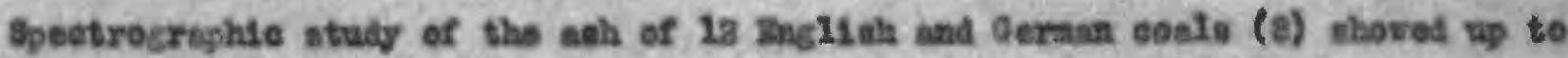
1 percent Be end 10 of the 12 exielnod had 0.01 peroent Bo or more. Stradles of the sabes of Rasedan conls $(22,29)$ give mack lowor f1curee for the beryllitus

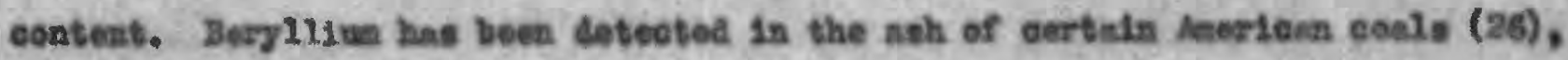
but no quatitative dats oze avaliable. 


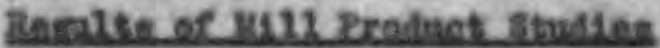

The berylliun eantest of nore then 1000 seples fren over 200 anes, M111.

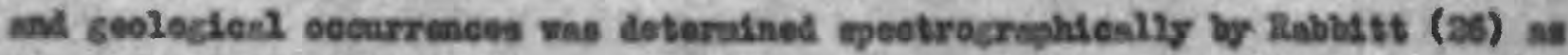

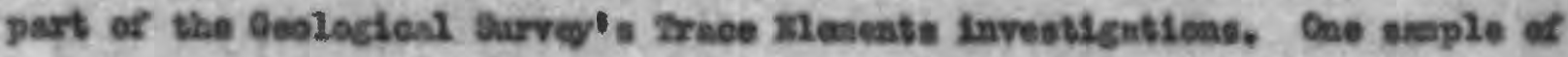
ore fros a tungeten propect in Yaviped County, Artzons, contelned a percent BeO. Tro others, both eontaot-altered lineatones in the vieinity of alkeli-nyenite

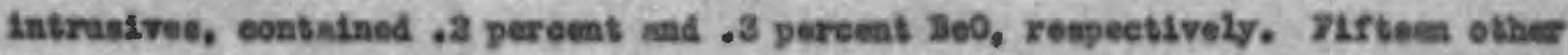

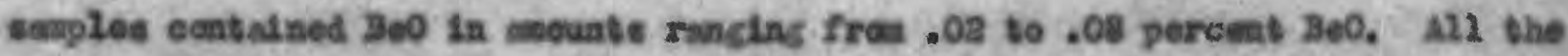

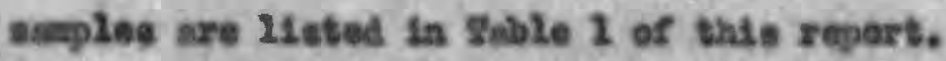

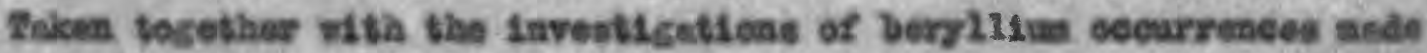
during the war, the realts oorrobornte long-atending eonelasions ragarding the detribution of berglidis in alnersle sad rocks. Berylliwe is conceatrated

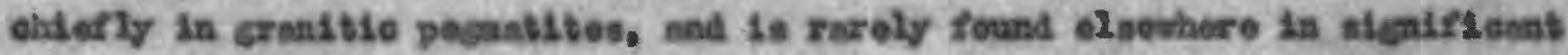

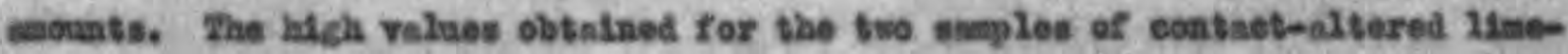

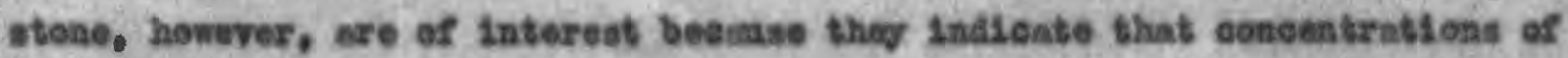

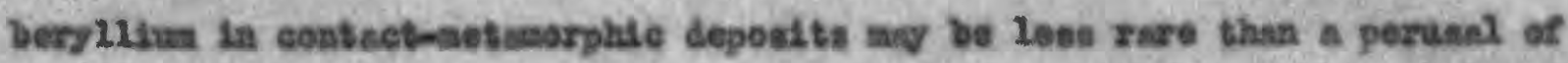
the 21 tesature pould mesent, and that sontaet mureoles around atkall-igyenite

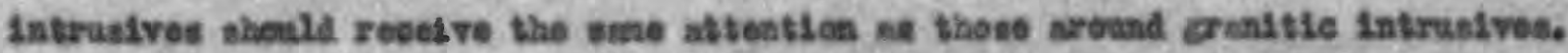

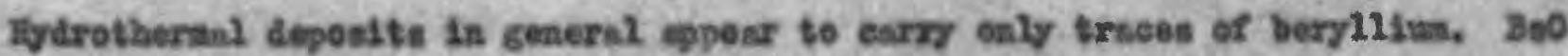
to the exteat of .02 percent ar wore wat found onty in suaples fron allis or

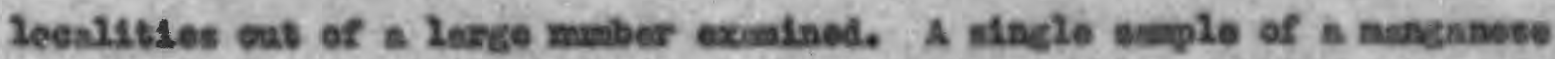

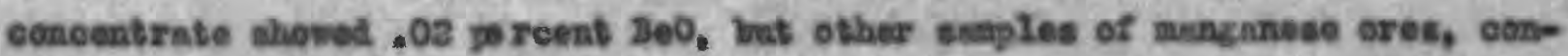
centrates, and tallinge aboed anly traees of beryllius. 


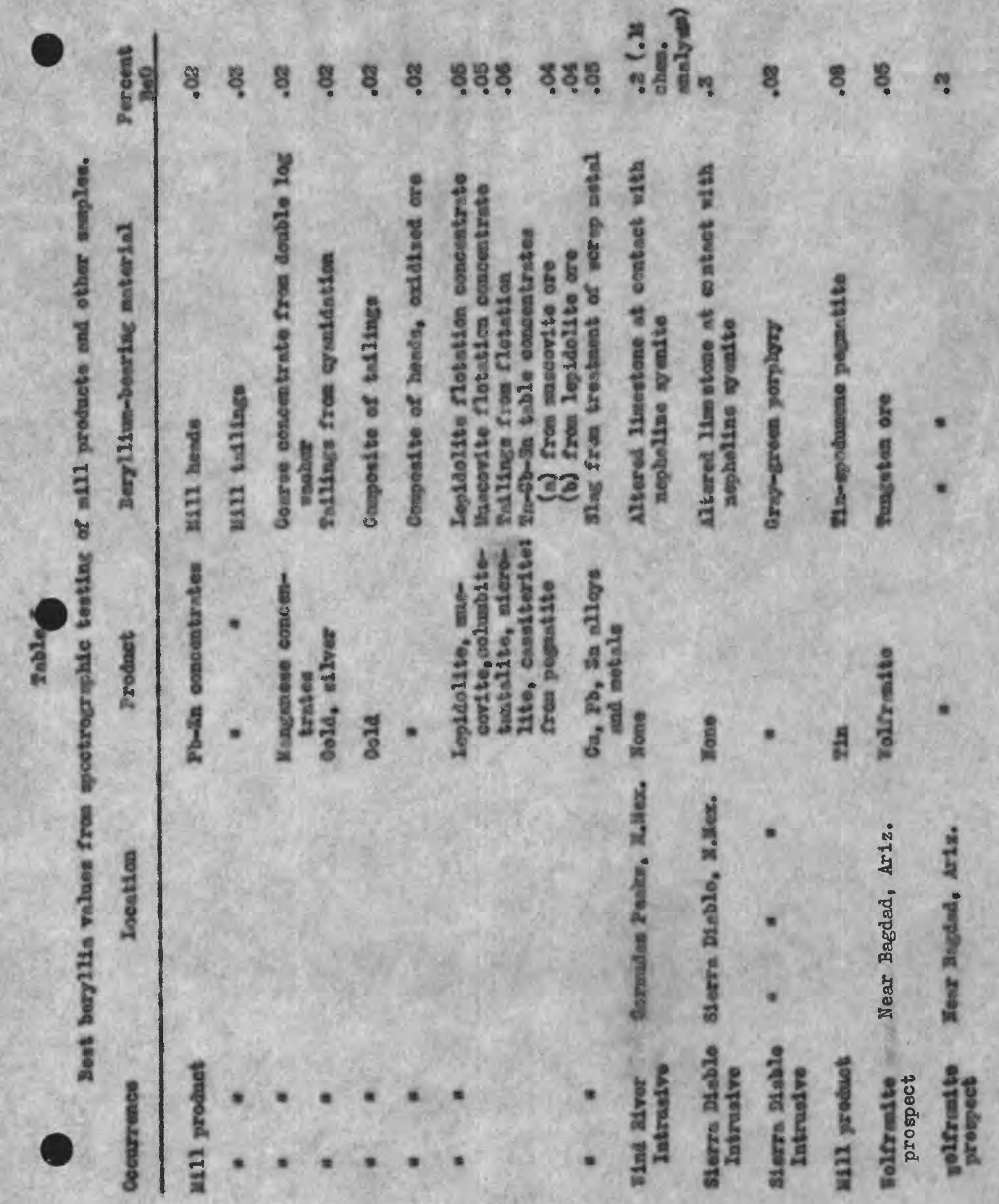




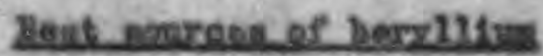

At present, beryllian in produced eatirely fren beryl, and all couserelel

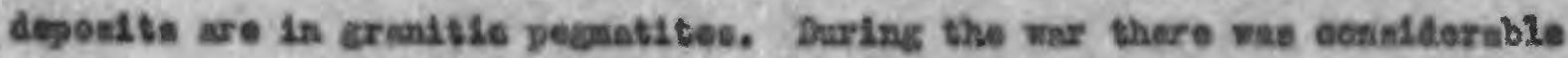

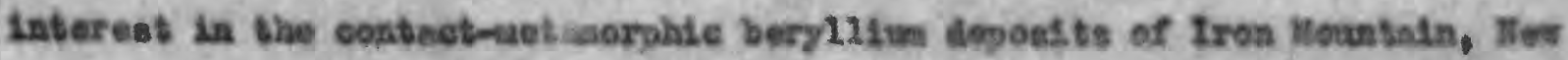
Meadeo, in which beryllium scoure larcely in the form of helvits $(5,10)$, bat

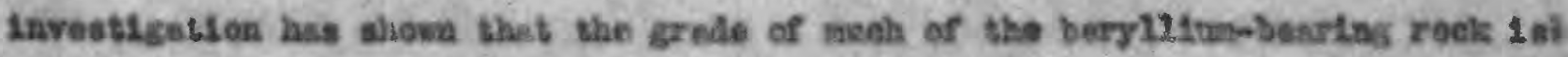
Iow wad the tumnige of berylifue present probebly is only noderntely ierco. In

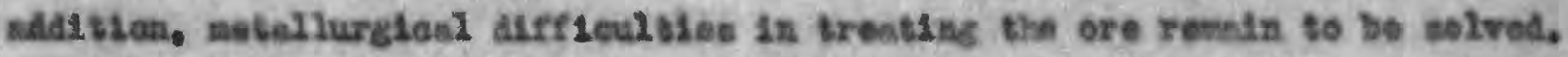

Tleuree for donestie prodectien of beryl sud for enounts of berry and

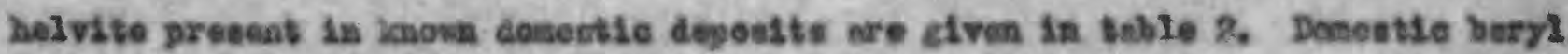
has bess produced alnost entirely as s byproduot of operntions for feldsper,

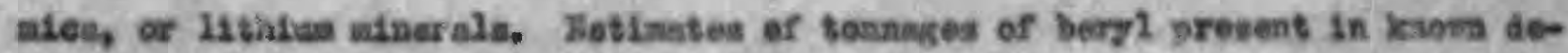
pealts are clvon under two headinge - land-ooperable beryl, ma miling beryli 1,0., betyl reeoverable only by alliking and flotabloa. Only the bonel-tepsrablo

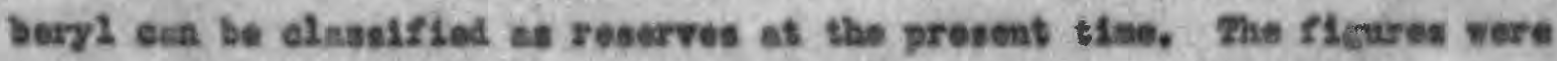
furnt sitad by vartoun aembers of the deolocteal garvey. They ore besed it pert on reeorde of pant produetion, but in inrge part on mensurements of eryotals In exporares of pecuntites and on celealstion of the ratioe betropn the arens occapled by beryl erystals and the totel srese of the expenures. Fone of the fleures for creden and teninges of beryl-beerleg materlal sre beed on explaration and sapiling by the U. S. Duresu of Yines.

Jleures for forel an productson of beryl ere etven is tablo 3 . The ants

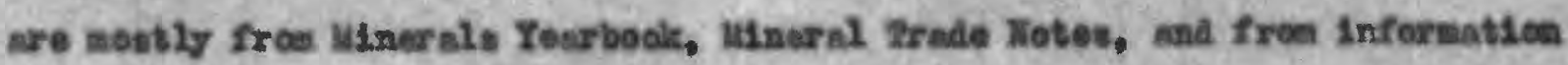

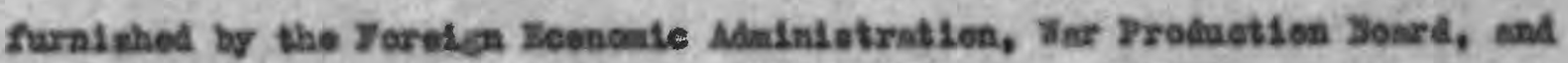

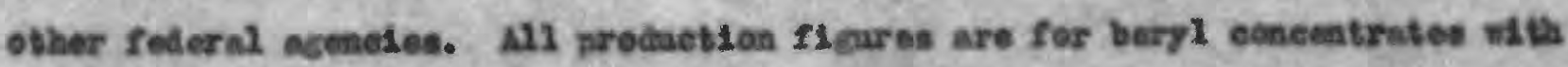
s minimas avernse centent of 8 percent 360 , Moot of the coneentrates ere 
reported to huve averaged 10 peroent 300 or aore. Ferelen protuetsen is partly lyproduet, partly fren operstiane conducted pelenerily for bergl, Jen

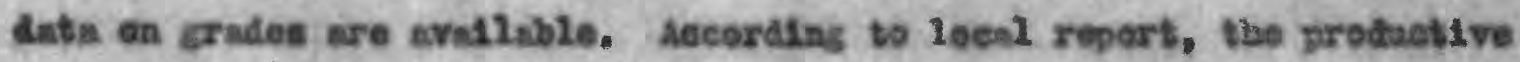
depoeits of narthenstern araed thowed an sversese reeovery of about. .3 pereent buryl froe roek mined. The feo dats avaliable for intien depondts sueseat grades, in terms of bery 2 reecresed 5 ros roek alned, of . 5 percent to

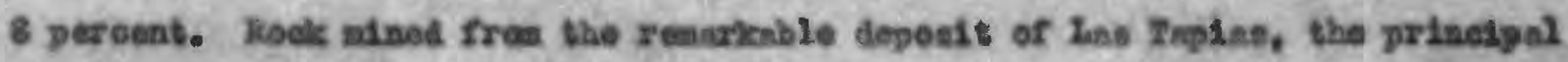
source of Argentine bery/ and probally the wont productive niskle depoet it in the

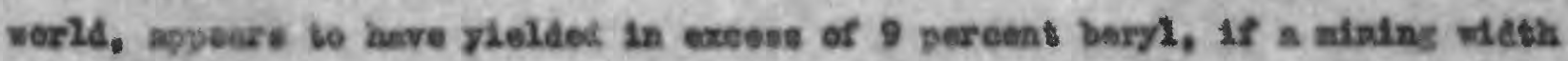
of 6 feet is anguned for purposes of colenintion.

The only caides to reserves in fordin countries ace production end loport 21guras, togetios wh consenta and rouch forceasts contained in reports of

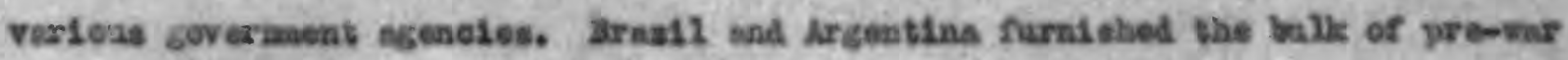
predaction and, together stih batralis sad Indla, mpplied the bulk of sur

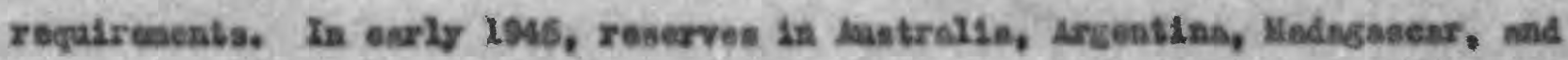
Union of South Atrice nare reported to be virtusily exheneted. Indie bed Brsall

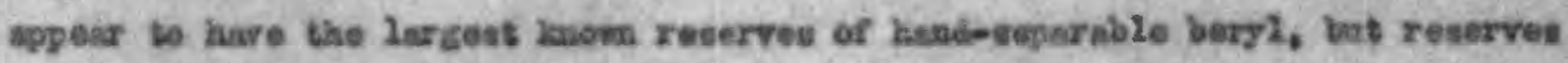

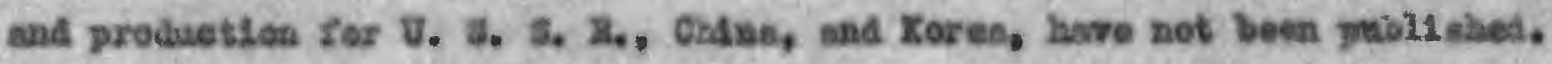

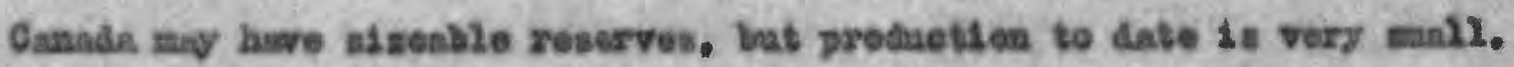


wale 2

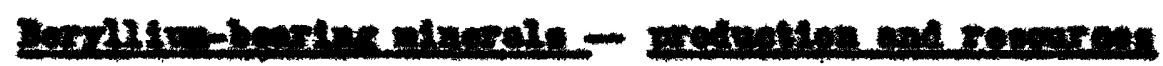

4. Dory - batted states prodection and rovourose

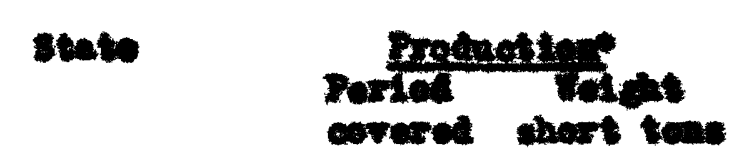

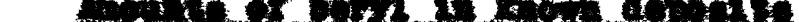

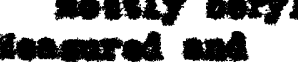
Indieted mort tous

moresived teme

erete

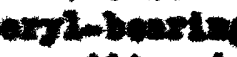

Tout atues burls Teamenes on Inatiesta shore tais sotal bark. anet tent

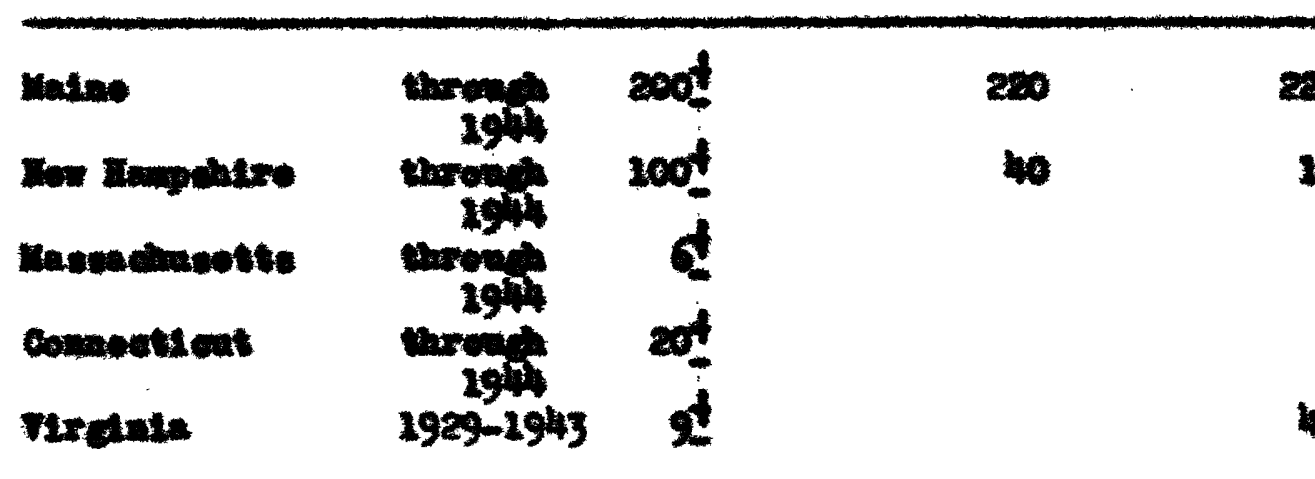

neto

south bovere

1879-1943 1269

nowine

oblereal

Ino nowe

+1943 <1

to son. 4901

- 1943

53 rame. is?

2090,2 is 1,0

15

$0.147 .0^{y}$

3

36

8

\subsection{6 to 0.5}

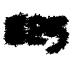

5

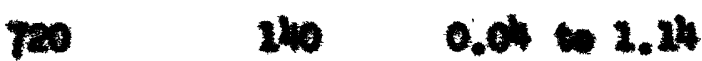

4

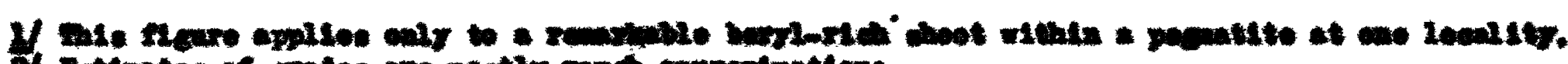
62

$0,2 \div 3,0$ 396

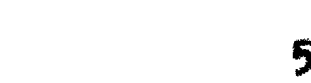

50.05102 .0
146
5

ases

0,05 : 2,0

$3 \mathbf{3}$

46

16.

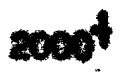

$0.5 \div 2.0$

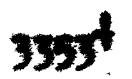

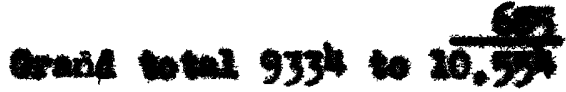

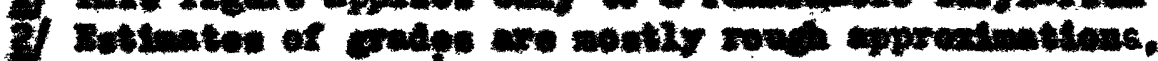

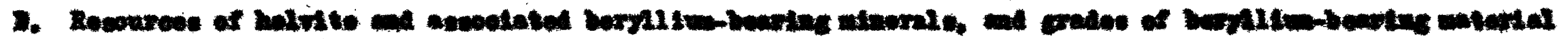

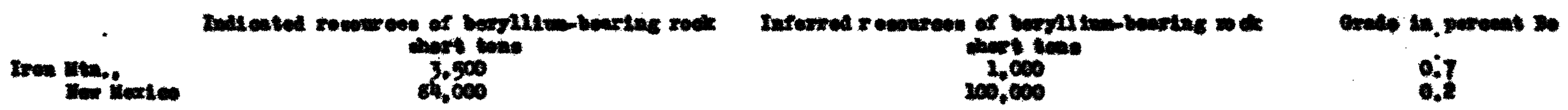


•

- 
Table 3

Ferel on nroduetion of berre.

Country

Anglo- Eoptian sudan

Argentine

Australla -

Irand

Irttich I. Arrias

Cinads

Indis and $\mathbf{W}$. dependeneles

liadagencer

Portugel

spaln

Southern Thodeate -

Southesent Sfrice

Daton of 8. Afrites

Ond ted states
1939

$--$

520

2.186

925

3

?

1.703

$$
1,634
$$

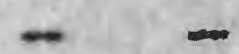

$-$

$1942 \quad 2943$

1944

$$
276 \quad 1,472
$$

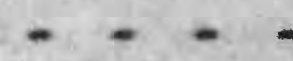

9 $52 \quad-$

17

1

$35 \quad$

,

67

1 เ

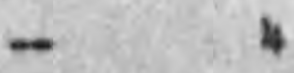

$\uparrow$

?

14

603

530

558

2,027

-

12 y

500 의

1. 185

219

1,46

1.000 2/

I

1 
Sagsentione for further invertigetions

hro ther Investigations should be direetad first toward Inereaning our lonomiadge of the bery mapplies present in donentle deposits. During the wror most of the lenom deaentle beryl-bearing peratites were exmalned by the

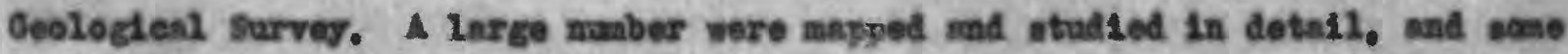
were explored by the Mureen of Wines and other ageneles, but in severni parts of the country there are large pepatiste-bearing arens that linve not been Inveatigated adequately for beryl. Fertine inventigations indieato, bowever, that the largest anowats of berf are in dopostin of milling grade, henes the

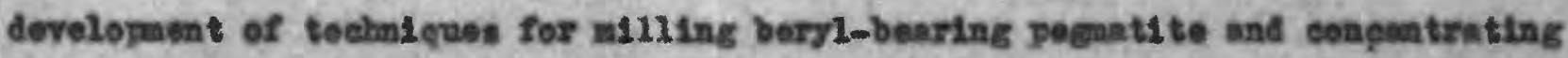
the beryl by notation Is a prorequi al te to elreable beryl produetion, It the proseat tine, operations would have to be mupported lexgely by recovery of felepper and other minerals from the poenatites.

The long-range outlook for beryl prodretion is involved with the trend In the feldopar induetry toward recovery of feldepar by flotatlon. If deopdte the development of this process, the induetry continues to rely en peesestites

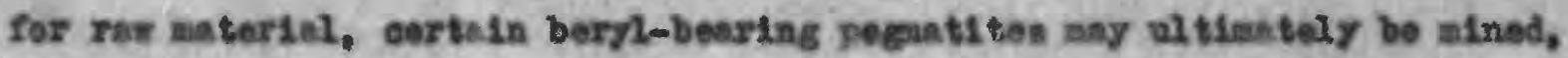
but if grad tes mapplant pegatites as the princlyal soureen of comereind feldspar, only s lerge Inereage in the price of beryl, or the develogment of 10- eost procesese for concentration, is likely to briag the beryl-bearing pegastitee Iato yroduetion. Iven granting the developrent of the neesesery techal ques, the lmediate outlook for mese milling of beryl-benring pegatites

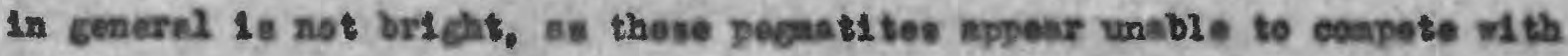
other pegatites that are largor, rieher in feldepar, and atruaturally nore favorable to loin-cost mintng. 
In eddition to strades of resources of bery 1 , ecertadn other potential

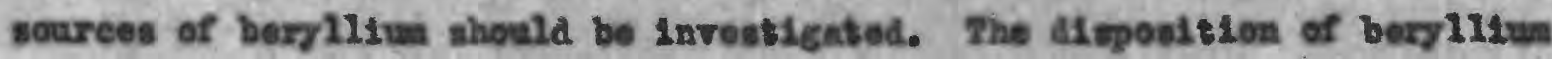
In the produetion of sluminum from bewaste whould be stadied to detersine whethor beryllum is coneentreted in the waste prodaets. Mepheline ryent te hat been suesented as a rem material for the prodrotion of aluoluran. If a plant is bullt for extrectlon of Alusinus froen nephelise symite ore from eley, the dispositien of the borylliwa present should be studled. Sfatenatie

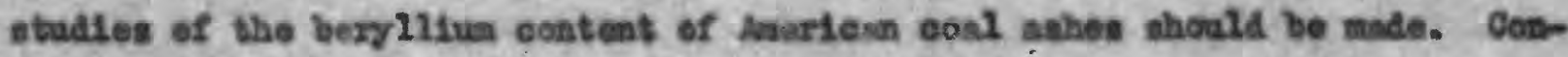
teot motenorpile doponits ahould be exinined for the presence of helvite and

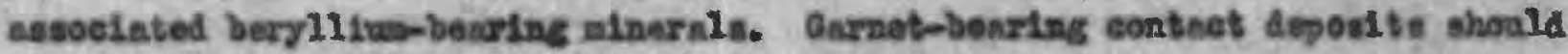

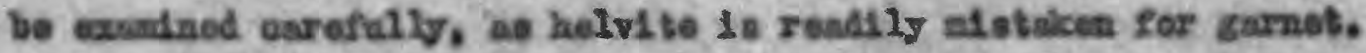




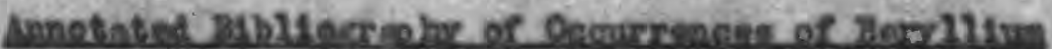

Deseriptlons of Individual depositn are not included. The oridnal pipern were seen except those for whlch reference to an abetraet jounal is diven,

1. Adlerson, J. S. Giestintry of the anthis

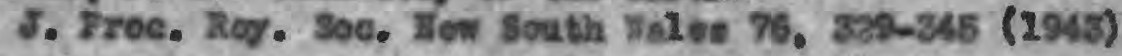

A suresy. The earth's erust is antinted to contain 0.0005 pereent

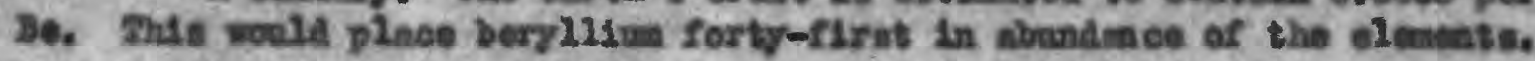

3. Borovick, 3. At and Gotann, J. D. Content of yore and other el eanente is

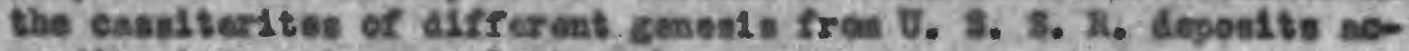
cording to spectrua annilyade date.

Compt. read. sond. sel. ग. R. 3. 2. 23, zsl-354 (2939) absent 20 most.

Berglitrin was deteeted in ean11 mount in sooe ceselteritos, but wes

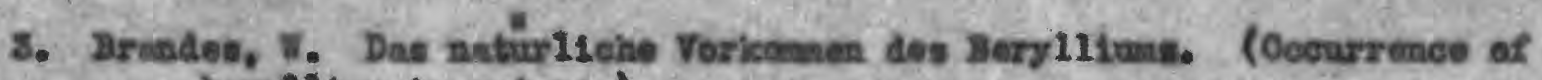
berylilian in nature.)

8. prakt. Qeo1. 41, 35-39 (1933)

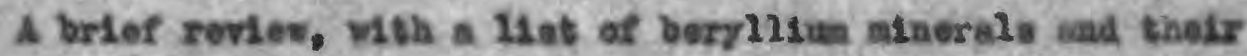
tepperatures of formatseis.

4. CIerike, 1. W. and taeluingtion, 1. 3. The componition of the earbi' s erunt.

V. \$. Geo1. Starvey Prop. Paper 137, $117 \mathrm{pp}$. (2924)

The beglitum content of the sarthis crust was estiasted on very Iittievildence to be 0.001 percent Bo.

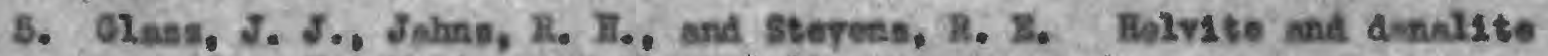
froa How Uexieo and the helvite group.

As. vineret. $39,163-192$ (1944)

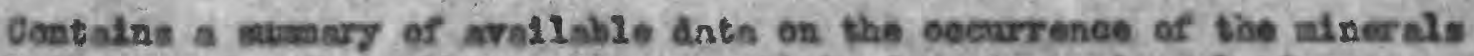
of the holvite croup and on the beryllius econtent of rarioul minerele froa Iron Mtn.. Ier Ilexteo.

6. Goldachatdt, T. H. Geocheat sohe Tertel lungegesetze der Elenante. IX.

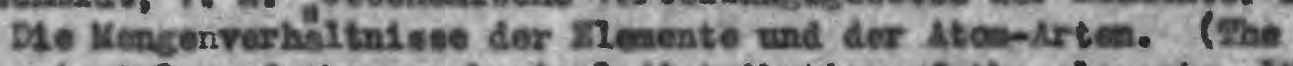
principles of tho ceochnites Afstribation of the elesents. IX. Alumdnnce of the eleants and 1sotopen.)

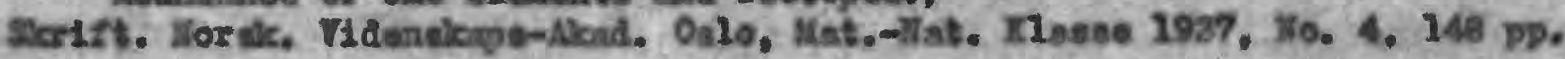

The ecoth's crust, Ineliallas the medimentery rocks, is eatimated to eontaln 0.0006 pereent Be. 


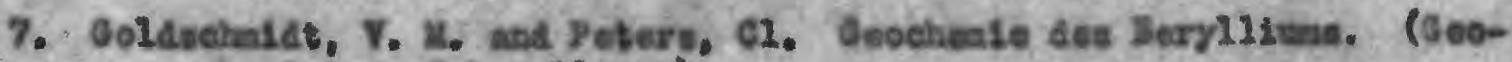
chenletry of berylliw.)

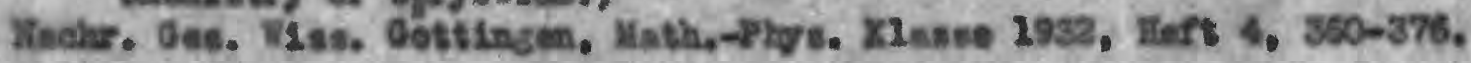

A dete1led spectrosraphic study of a larce numbe of sumples. The everige content for all eruptive rocka is probsbly about 0.0003 percent 30. Grand tee averese perhen 0.0004 pereent 10 , aeghiline eyent tee 0.004 percent Bet other roeks hive mieh lower berylliwa contents. Beryilie is notsbly high in oustnet mibtenorphte depondis. In selinentary processet, baryllim

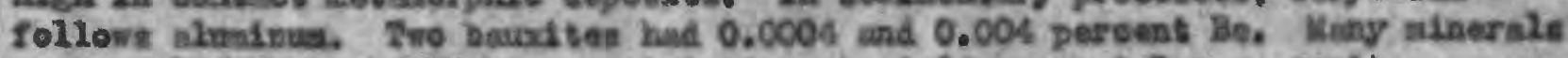
Fere canlysed; the follomins contalied op to 0.04 percent Bet maeovite. biotite, Inngeldite, toumiline, neplatine, secirize, buricevdldte, axindse, and idocrise (remerinhtte).

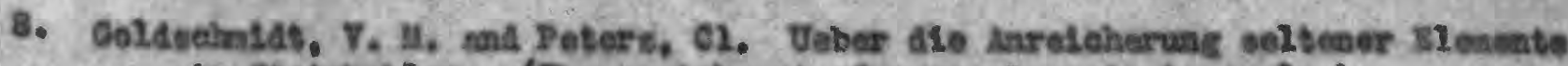
2in Steinicohlan. (The enrichent of rare elesents in coels.)

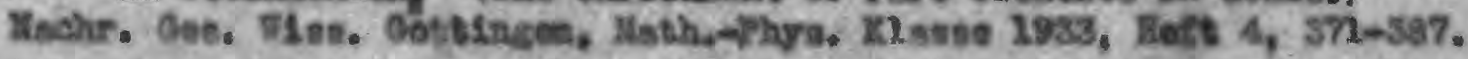

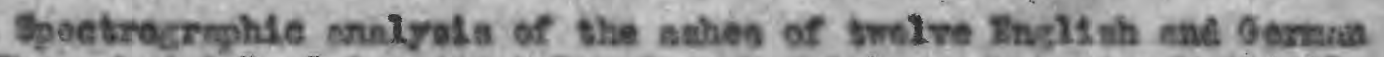
goals. Three hed $0.1-1.0$ percent Be, four had 0.1 percent, two had 0.01 0.2 percent, ane land 0.01 percent, two had 0.002 pereent. The anibes of

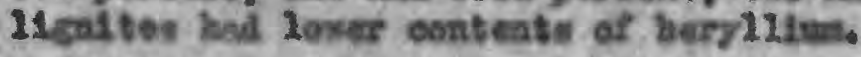

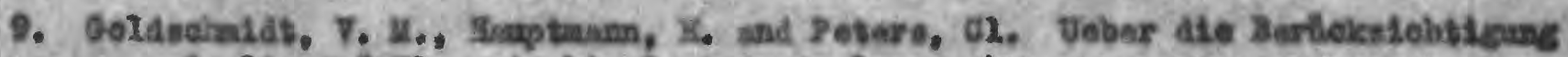
"ealtener" mesente blo Gentelin-Analysen. (Consideration of "rare" Yaturatanensohat tea 20, 362-2165 (1933) elements in rock-analyses)

The followles new deternitaticas are dvent (1) A nixture of 21

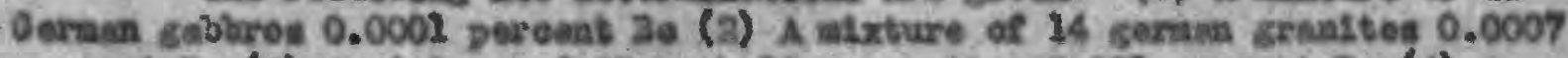
percent 3o (3) A mixture of 23 nepheline syenites 0.001 percent Be (1) A

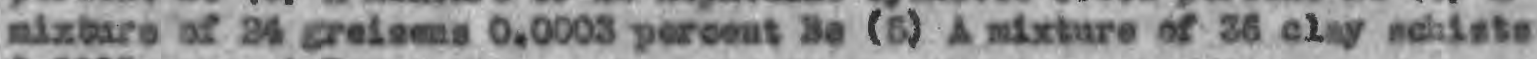
0.0005 percent Be.

10. Jahns, J. It ind Glase, J. J. Berylliva and tancoten depositin of the Iron

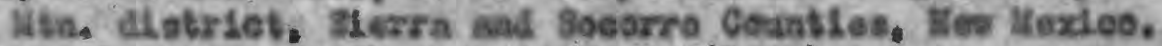

v. 3. Qeal. Burveg luil. $945-\mathrm{C}, 45-70$ (124)

4 atudy of the helvile depontte.

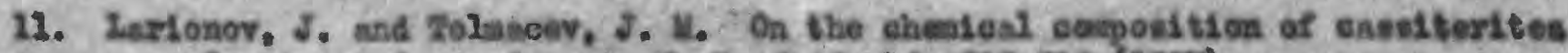
Caspl. rond. soad. sc1. V. 2. 3. 3. 14, $303-306$ (2937).

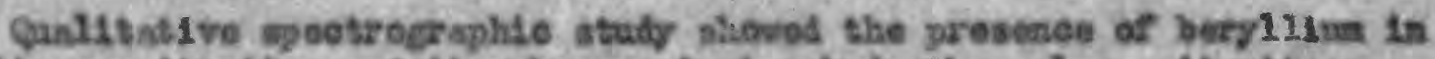

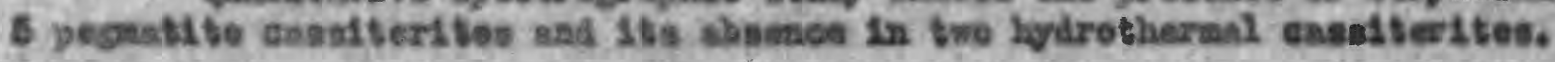

12. Hogerenlos, V. A. The oecurrence of vasedius, beryllius, and boron in the ain of seap coeld.

Frav. 13. bloctoebin. nond, se1. U. 21. 3. 3. 4, 265-270 (In German 2n) $(1937)$, Ches. Abetriats $32,77 \% 0$ (2938).

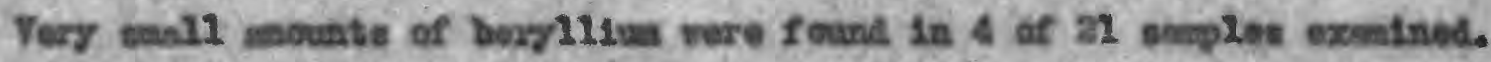




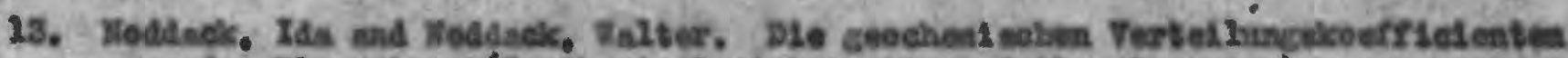

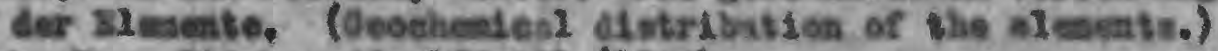

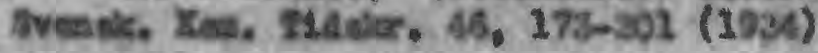

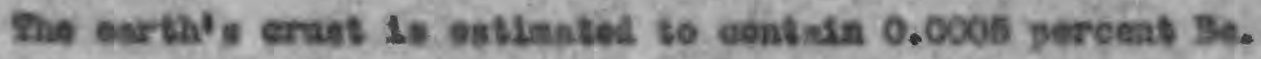

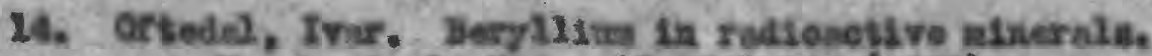

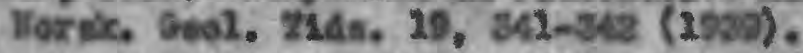

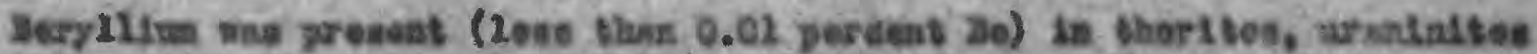

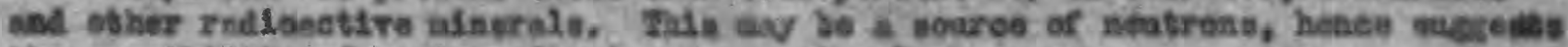

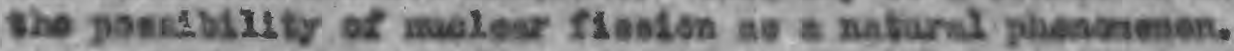

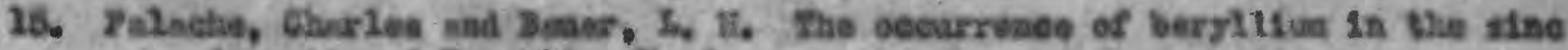
Eeposite of Trabldin, X. J.

le. Mineral. 16, 30-23 (1930)

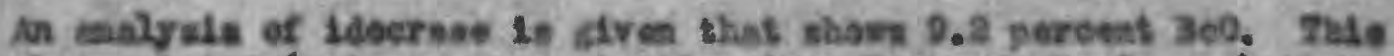

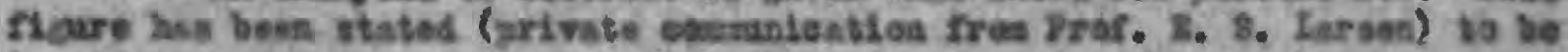
in exroz.

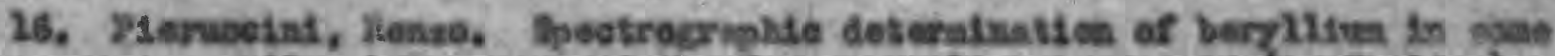

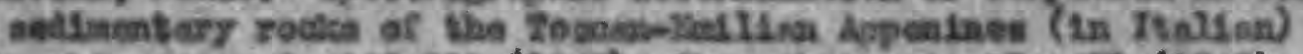

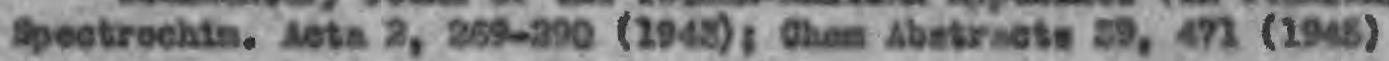

Sees sedineatery roelis centatned 0.0001 to 0.00002 perents Be.

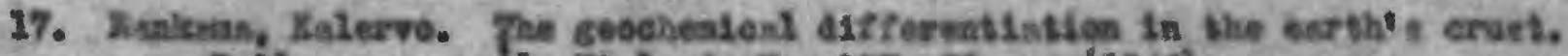

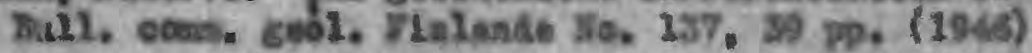

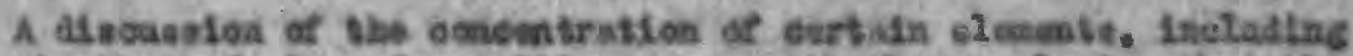

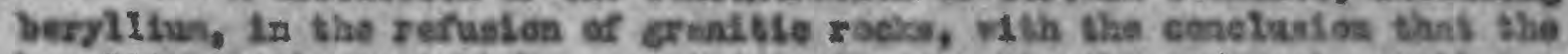

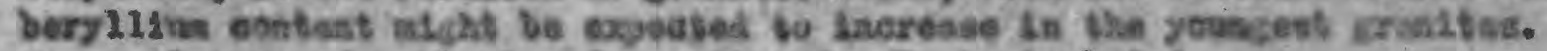

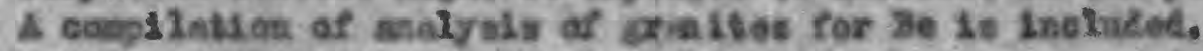

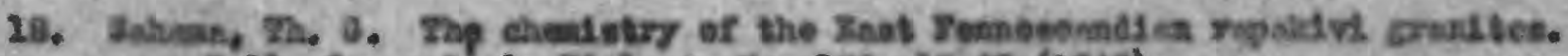

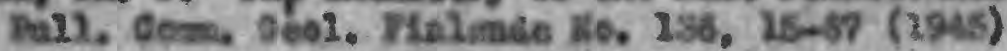

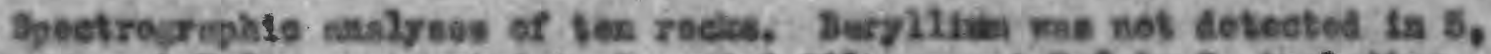

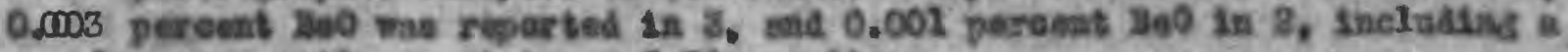
ogiple representing a alxtare of if crand tes.

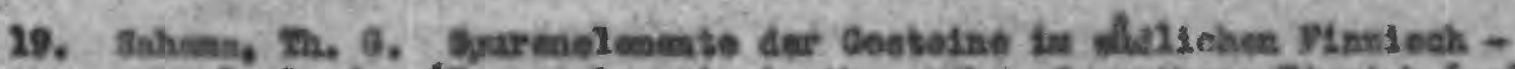

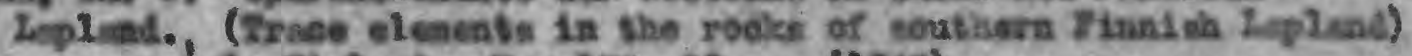

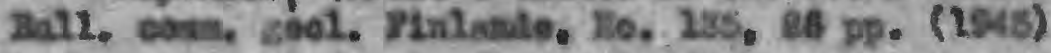

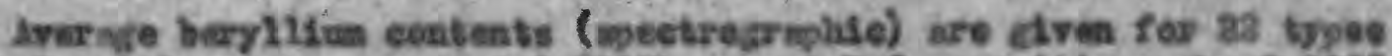
of roekt. Granilie rocks svernged 0.0003 poreent 300 , evenitie rocks 0.0006

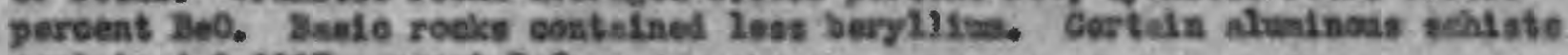
evatalned 0.0003 perceot ze0. 


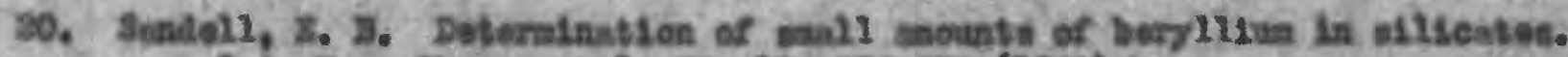

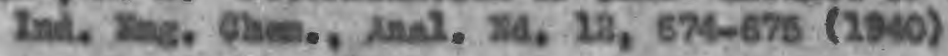

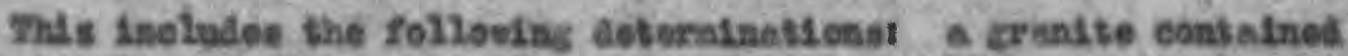

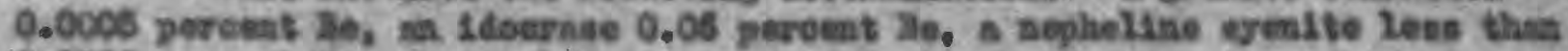
0.0008 pereent 30 .

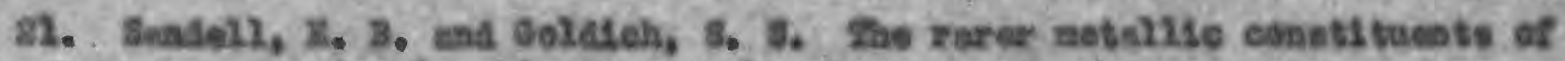
save hiverlem igneves rocice.

s. 0501. 51, 09-215, 167-182 (1933)

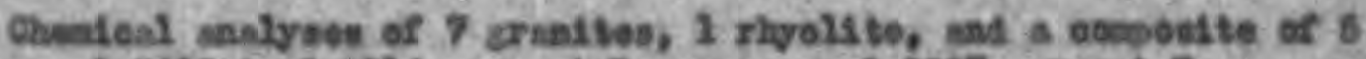

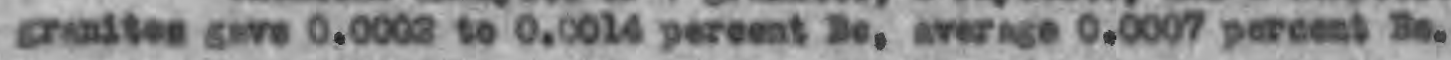

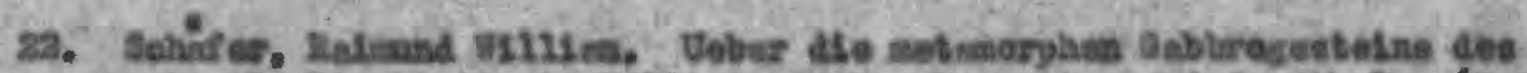

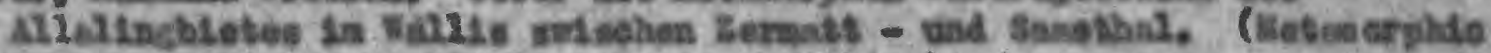

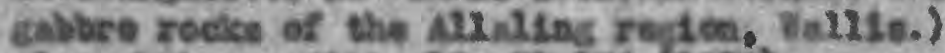

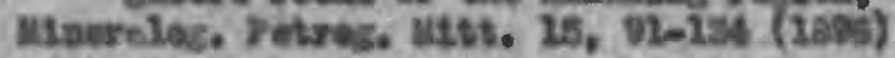
pereent 3eQ.

Aavlyaes are ctron of two hadtea tiant eontulned 1.60 and 1.04

32. Stregeb, I. I. Jergl (In Nasadian)

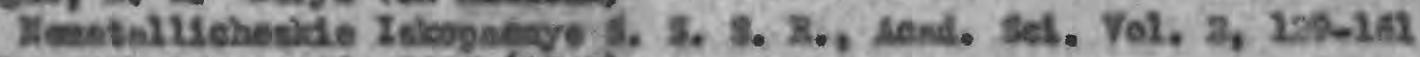
(1943) I Ches, Abutrnets 39, 3226 (1945)

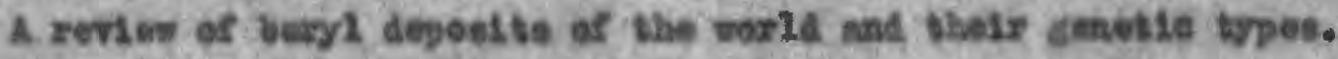

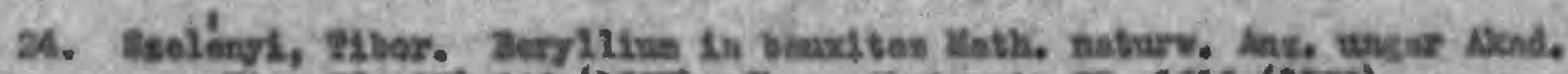

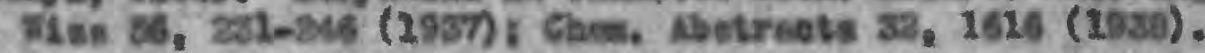

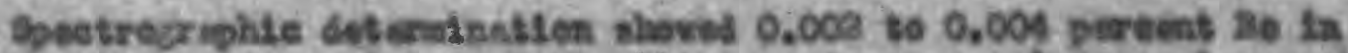

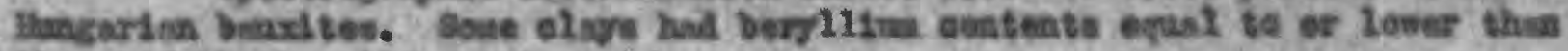
thowe of the bandtes.

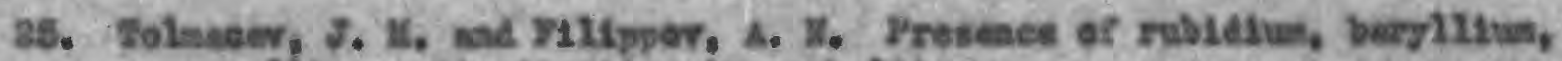

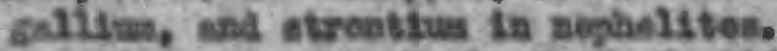

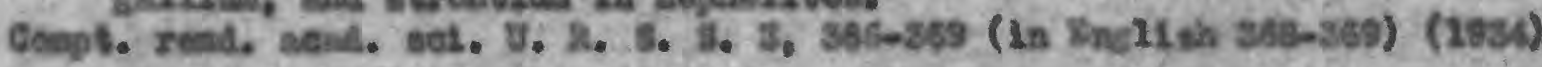

Spestrogruphie stady follentas ehendesl ooneentration shomet 0.0003 to 0.022 percesat 30 , avurece 0.006 peroent $\mathrm{Be}$, in 8 nephelinet.

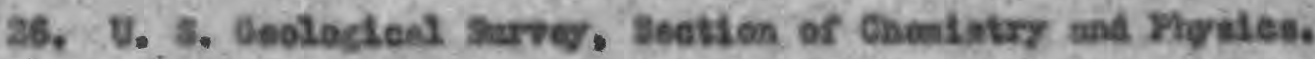

Thyoblished dets.

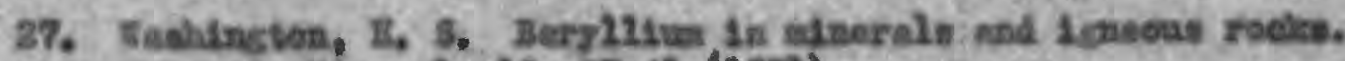
16. vineral. 26, zi-41 (193)

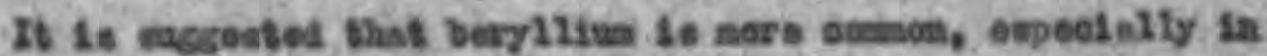

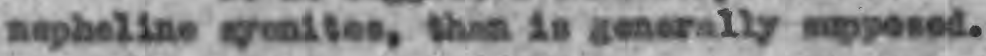




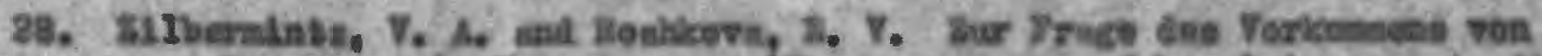

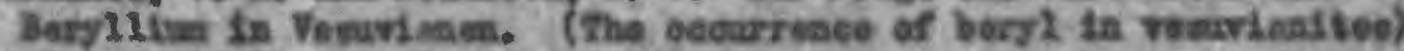

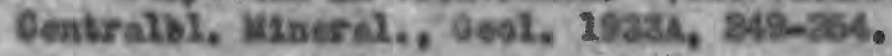

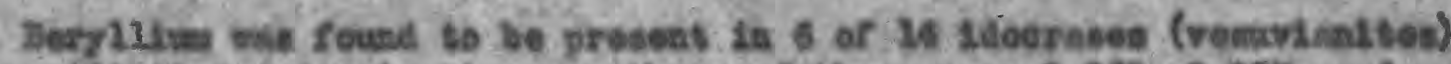

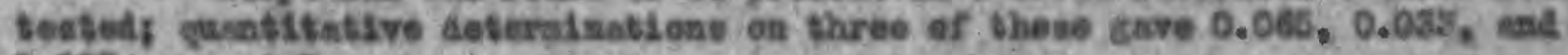
0.003 percent Ble.

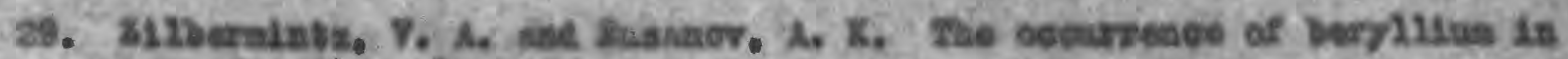
foked1 cesla.

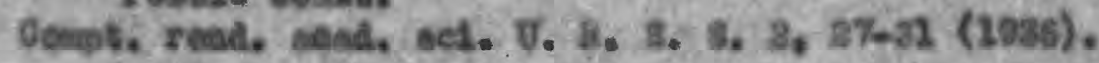

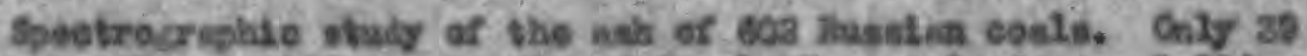

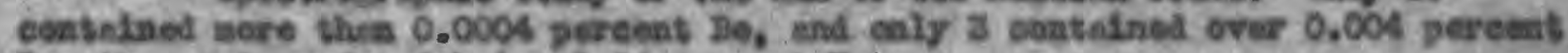
Bo, the naxtira found bednc 0.06 perevat Me. 